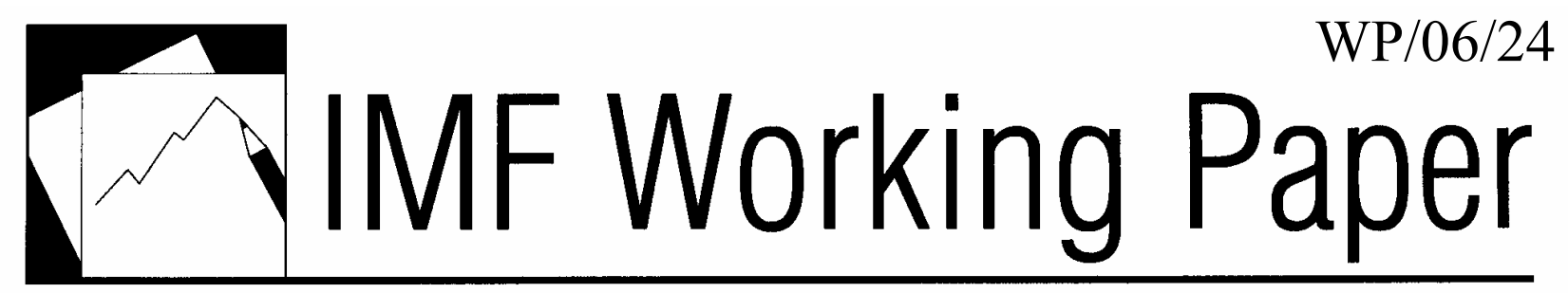

\title{
Implications of Quasi-Fiscal Activities in Ghana
}

Mali Chivakul and Robert C. York 



\title{
IMF Working Paper
}

\section{African Department \\ Implications of Quasi-Fiscal Activities in Ghana}

\author{
Prepared by Mali Chivakul and Robert C. York $^{1}$ \\ Authorized for distribution by Samuel Itam
}

January 2006

\begin{abstract}

\section{This Working Paper should not be reported as representing the views of the IMF.} The views expressed in this Working Paper are those of the author(s) and do not necessarily represent those of the IMF or IMF policy. Working Papers describe research in progress by the author(s) and are published to elicit comments and to further debate.

This paper assesses the scope and coverage of quasi-fiscal activities (QFAs) in Ghana. We find that while QFAs have been reduced recently, they remain significant. The extensive nature of these activities has several macroeconomic and structural policy implications. An extended measure of public sector operations, including QFAs, presents a clearerpicture of Ghana's fiscal stance and fiscal adjustment from one for the central government alone; QFAs have led to serious distortions in energy and water consumption; and they have distorted the investment decisions of both public enterprises and the private sector.
\end{abstract}

JEL Classification Numbers: E62, H11, H54, H60

Keywords: Ghana; quasi-fiscal activities

Author(s) E-Mail Address: mchivakul@imf.org; ryork@imf.org

\footnotetext{
${ }^{1}$ We would like to thank, without implication, Samuel Itam, Saul Lizondo, Noriaki Kinoshita, Zaijin Zhan, James Daniel, Pierre Laporte, and Christian Josz for helpful comments and suggestions on an earlier draft of this paper. We would also like to express our appreciation to the Ghanaian authorities for providing the extensive data used in this paper. Any errors or omissions remain our own.
} 


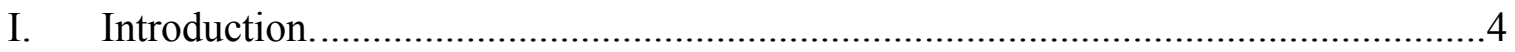

II. Fiscal Developments in Perspective................................................................5

III. Conceptual Framework for Quantifying Quasi-Fiscal Activities ..........................10

IV. The Scope and Coverage of Quasi-Fiscal Activities ........................................12

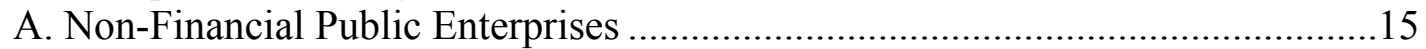

Volta River Authority ............................................................... 15

Electricity Company of Ghana........................................................18

Ghana Water Company Limited .....................................................21

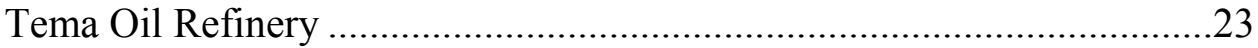

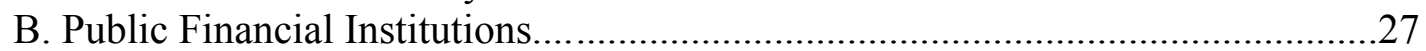

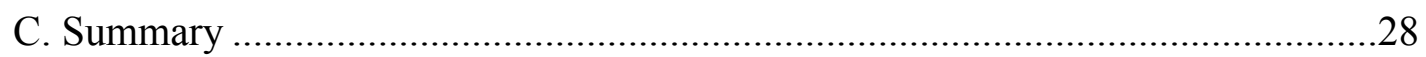

V. Quasi-Fiscal Activities and the Fiscal Position ................................................29

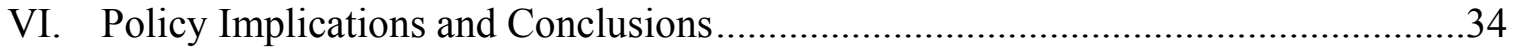

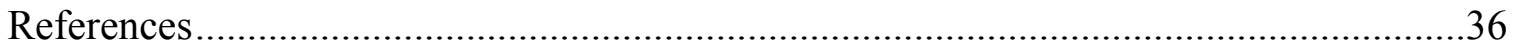

\section{Text Boxes}

1. Types of Quasi-Fiscal Activities........................................................................ 11

2. Commercial Orientation of Public Enterprises in Ghana .......................................13

3. The Public Utilities Regulatory Commission (PURC) ...........................................19

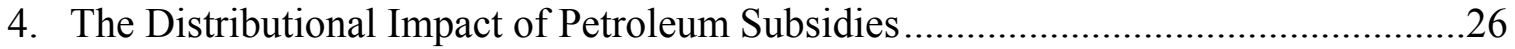

5. The Central Bank's Holdings of Government Securities ........................................

6. Contingent Liabilities: The Case of Ghana Airways ................................................33

Figures

1. Indicators of Public Debt Under Alternative Scenarios, 2004-23 ............................8

2. Net Present Value (NPV) of Ratio of Public Debt to GDP, 2005-23 .........................33

Tables

1. Summary of Central Government Operations, 1993-2004.....................................6

2. Operations of the Large State-Owned Enterprises, 2000-04 .................................. 9

3. Tax and Dividend Payments by State-Owned Enterprises, 1999-2003 .....................15

4. Budget Subsidies to State-Owned Enterprises, 2003-05 .....................................15

5. Estimated Quasi-Fiscal Activities of the Volta River Authority, 2000-04................18

6. Estimated Quasi-Fiscal Activities of the Electricity Company of Ghana,

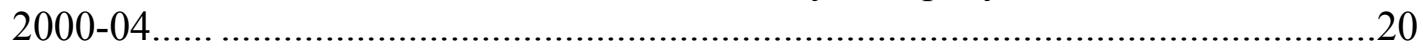

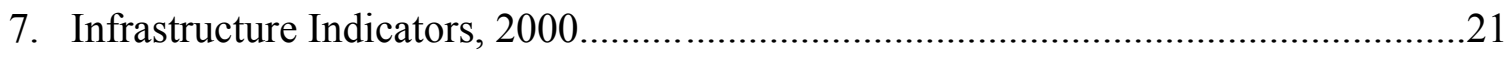

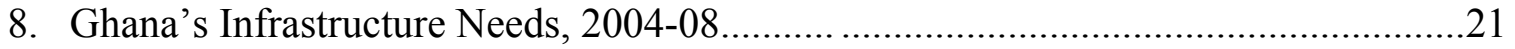

9. Estimated Quasi-Fiscal Activities of the Ghana Water Company, 
2000-04. .23

10. Estimated Quasi-Fiscal Activities of the Tema Oil Refinery, 2001-03_..................25

11. Estimated Quasi-Fiscal Activities of the Bank of Ghana, 2000-04...........................29

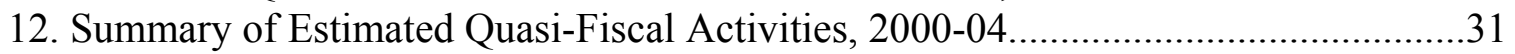

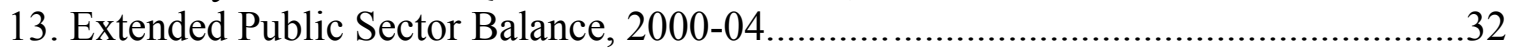

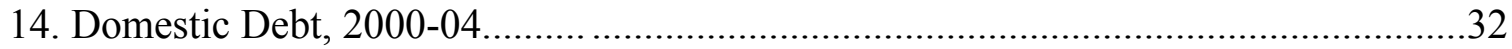

Appendices

I. Alternative Approaches to Estimating Quasi-Fiscal Activities .................................38

II. Assumptions Underlying the Public Sector Debt Sustainability Analysis ..................40

Appendix Tables

A1. Volta River Authority: Financial Statements, 2000-04

A2. Electricity Company of Ghana: Financial Statements, 2000-04 ...............................42

A3. Ghana Water Company Limited: Financial Statements, 2000-03 ............................43

A4. Tema Oil Refinery: Financial Statements, 2000-04.............................................44

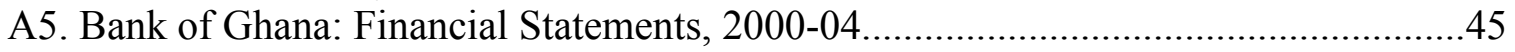




\section{INTRODUCTION}

After gaining independence in 1957, Ghana brought most of the economy under government control, and by the early 1980s, the public sector completely dominated production. Publiclyowned enterprises were involved in almost all sectors, including finance and banking, and some served to fulfill social policy goals. Reforms to liberalize the economy and reduce government involvement began in 1983, and included an extensive program of privatization in which 200 public enterprises were eventually divested.

The government continues to fully own 35 non-financial enterprises-including some of Ghana's largest companies-and is a majority shareholder in some 200 others. While some of these enterprises are profitable, the vast majority operate at a loss requiring budgetary or other forms of government support to continue their operations. A large number of these enterprises function as quasi-fiscal institutions, providing social safety nets, subsidies, and tolerating arrears and non-payment. While these quasi-fiscal activities (QFAs) have lessened over time, they remain significant in Ghana. In addition, some public financial institutions-including the central bank-also engage in such activities.

QFAs are used by governments to achieve a number of social, political and economic objectives, and, consequently, they have broad macroeconomic and structural implications.

- Where such activities are large, the size of government may not be accurately reflected in conventional measures of the overall fiscal balance, tax revenue, and expenditure. Therefore, accounting for QFAs using a broad measure of public sector operations can provide a different picture of the fiscal stance and fiscal adjustment.

- $\quad$ QFAs can result in implicit contingent liabilities, thus affecting both fiscal and potentially external debt sustainability. This can occur, for example, if contingent liabilities are created by government guarantees on domestic and foreign borrowing by public enterprises.

- $\quad$ QFAs are often undertaken by administrative decision, are not reported in the budget or budget reporting, and, subsequently, escape legislative and public scrutiny. This lack of transparency can also result in QFAs that are self-perpetuating. In addition, there is no "contestability" over the use of scarce public resources, unlike the scrutiny placed on the allocation of budgetary expenditures.

- In many countries, QFAs can give rise to losses from the central bank that can contribute to monetary expansion. Some forms of financing the QFAs may have the same adverse effects as financing government expenditures, such as crowding-out, and increasing debt.

- $\quad$ There may be adverse effects on the financial system through moral hazard-directed or excessive lending by financial institutions to public enterprises under the presumption that the government will bail them out if a problem arises. 
- $\quad$ Since they have similar effects to explicit taxes and subsidies, QFAs distort resource allocation and generate unwanted and non-transparent redistribution, with consequences for equity and fairness. The distortions to resource allocation could also undermine the efficiency of the enterprises concerned, with adverse consequences for economic growth.

This paper seeks to assess the scope and coverage of QFAs in Ghana, making use of data for a limited number of large public enterprises and the central bank. ${ }^{2}$ In this regard, the paper focuses on three key issues (i) the mechanisms used for the non-transparent subsidization of the private sector (both enterprises and households), (ii) who benefits from these subsidies, and (iii) how the transfer of resources is financed. The paper also assesses the implications of QFAs for Ghana's fiscal stance and sustainability, when the fiscal coverage is extended beyond the central government.

The paper is organized as follows. The next section provides an overview of recent fiscal developments, to put the discussion of QFAs in perspective. The framework employed in this paper for quantifying QFAs for non-financial and public financial institutions is outlined in Section III, and this is followed by a description of such operations and estimates of their magnitude for four major state-owned enterprises and the Bank of Ghana in Section IV. A brief description of measures that are being undertaken to reduce these operations is also highlighted. Section V discusses the implications of QFAs for Ghana's fiscal position, and Section VI offers some policy implications and conclusions.

\section{Fiscal Developments In Perspective}

After a period of instability during the 1990s, the fiscal position of the central government has strengthened considerably. During the 1990s, the overall fiscal deficit (including grants) averaged about 9 percent of GDP, but it has declined steadily since then to about $3 \frac{1}{2}$ percent of GDP in 2004 (Table 1). This improvement is partly attributed to strong growth, but new tax measures, enhanced revenue administration, and expenditure discipline have all played a role. Tax revenue is at its highest level at about 24 percent of GDP, and this has allowed recurrent expenditure to rise to more than 20 percent of GDP. On present estimation, the government achieved its medium-term objective outlined in the Ghana Poverty Reduction Strategy, of halving the ratio of domestic debt to GDP from the end-2002 level by end-2005 (about $11 \frac{1}{2}$ percent of GDP). The extent of fiscal consolidation over a relatively short

\footnotetext{
${ }^{2}$ Assessing the scope and coverage of QFAs in any country is complicated by the lack of reporting on these activities. The IMF's Manual on Fiscal Transparency urges the reporting of these activities. In contrast, the Organization for Economic Co-Operation and Development best practice guidelines on fiscal reporting does not extend to QFAs. The present study makes use of the most comprehensive data currently available on Ghana's public enterprises, although the quality and timeliness of this financial and operating data is relatively weak (for more details concerning the data, see Ghana: Statistical Appendix, 2005b, Attachment IV at http://www.imf.org/external/country/GHA/index.htm).
} 


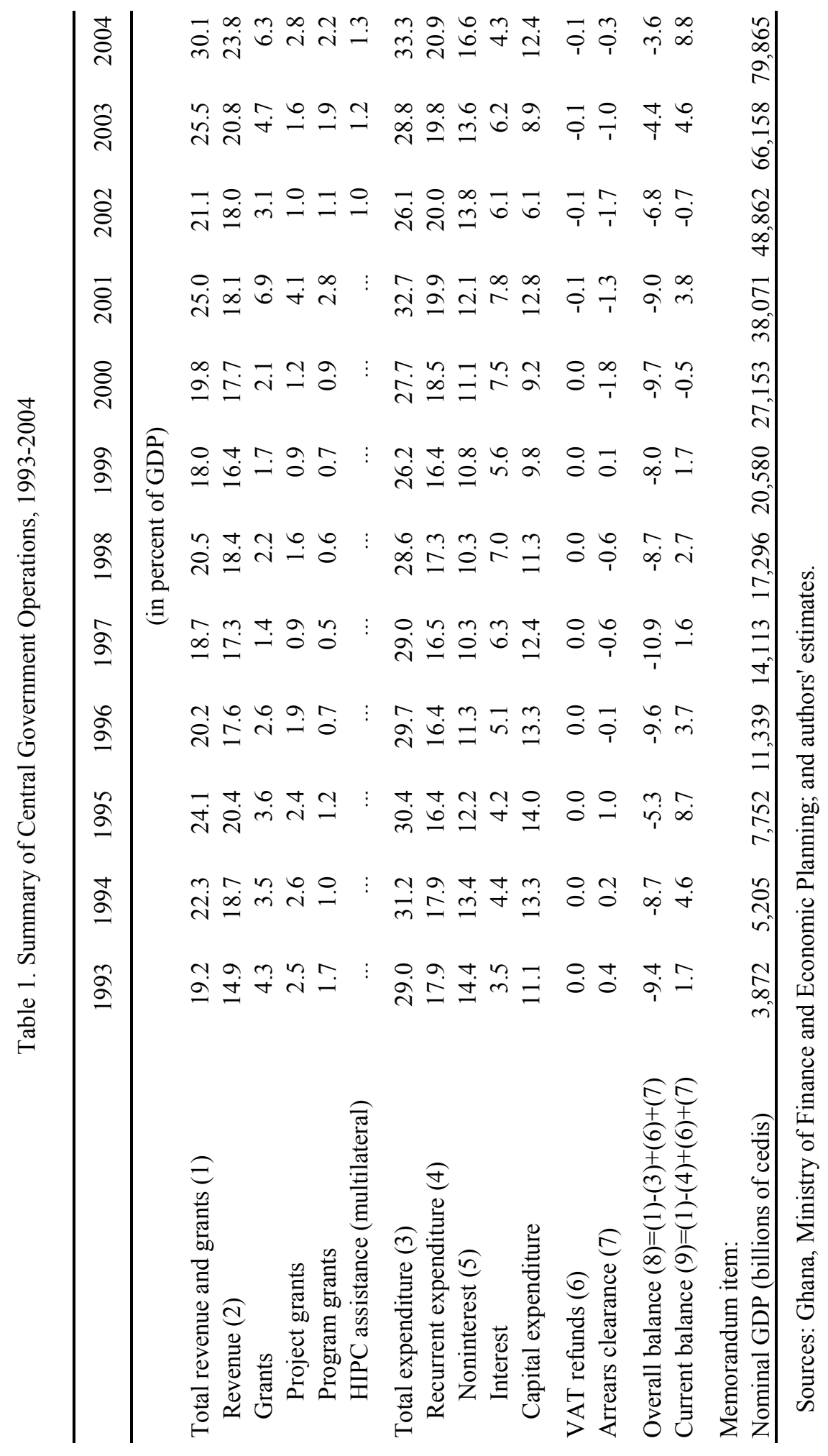


timeframe has also been accompanied by the desired decline in short-term interest rates, and the expansion of credit growth to the private sector.

The improvement in the fiscal position, strong growth (especially since 2000), and more recently, debt relief from the enhanced Heavily Indebted Poor Countries (HIPC) Initiative has strengthened Ghana's external debt outlook. ${ }^{3}$ The total stock of public- and publiclyguaranteed external debt has declined from about 124 percent of GDP in 2000, to 90 percent in 2004. A debt sustainability analysis (DSA) shows that Ghana's external debt is sustainable, with the net present value (NPV) of debt to GDP ratio and debt service to revenue ratio remaining well below HIPC thresholds (Figure 1). ${ }^{4}$

This picture of the fiscal position and debt sustainability is, however, only partial, since it takes account only of the central government. The scope of fiscal policy in Ghana goes well beyond the central government, encompassing local governments, statutory funds, the social security system, non-financial public enterprises and financial institutions.

Public enterprises play an important role in Ghana's economy, given their size and continued involvement in nearly every sector. For the non-financial public enterprises, the eight largest wholly publicly-owned entities had total assets valued at more than 60 percent of GDP in 2003, and total liabilities of nearly 30 percent of GDP (Table 2). These eight public enterprises had an overall deficit of 9.2 percent of GDP in 2000, which was nearly as large as that of the central government during that period. The position of the public enterprise sector has improved dramatically since then, however, with an overall surplus emerging during 2003.

A more complete fiscal picture of the public sector should, therefore, include the financial position of the non-financial, non-commerical public enterprises. Moreover, it is important to clarify how public enterprises' liabilities could affect fiscal sustainability. For Ghana, an important influence on the public sector's performance outside the central government is quasi-fiscal activities carried out both by non-financial enterprises and by financial institutions. The focus on QFAs is not meant to downplay the importance of the overall financial position of public enterprises-particularly those that are non-commercially oriented-and the fiscal implications for the wider public sector (see below). Indeed, losses of these enterprises must also be financed, and profits must be returned to the budget through transfers or dividends.

\footnotetext{
${ }^{3}$ In July 2004, Ghana reached the completion point under the enhanced HIPC Initiative, resulting in irrevocable debt relief amounting to US\$2.2 billion in net present value terms. The relief is effective from end-2003.

${ }^{4}$ The debt sustainability analysis does not take account of the recent Multilateral Debt Relief Initiative, for which Ghana will receive debt (stock) relief from the IMF amounting to US\$316 million.
} 
Figure 1. Indicators of Public Debt Under Alternative Scenarios, 2004-23 1/ (In percent)
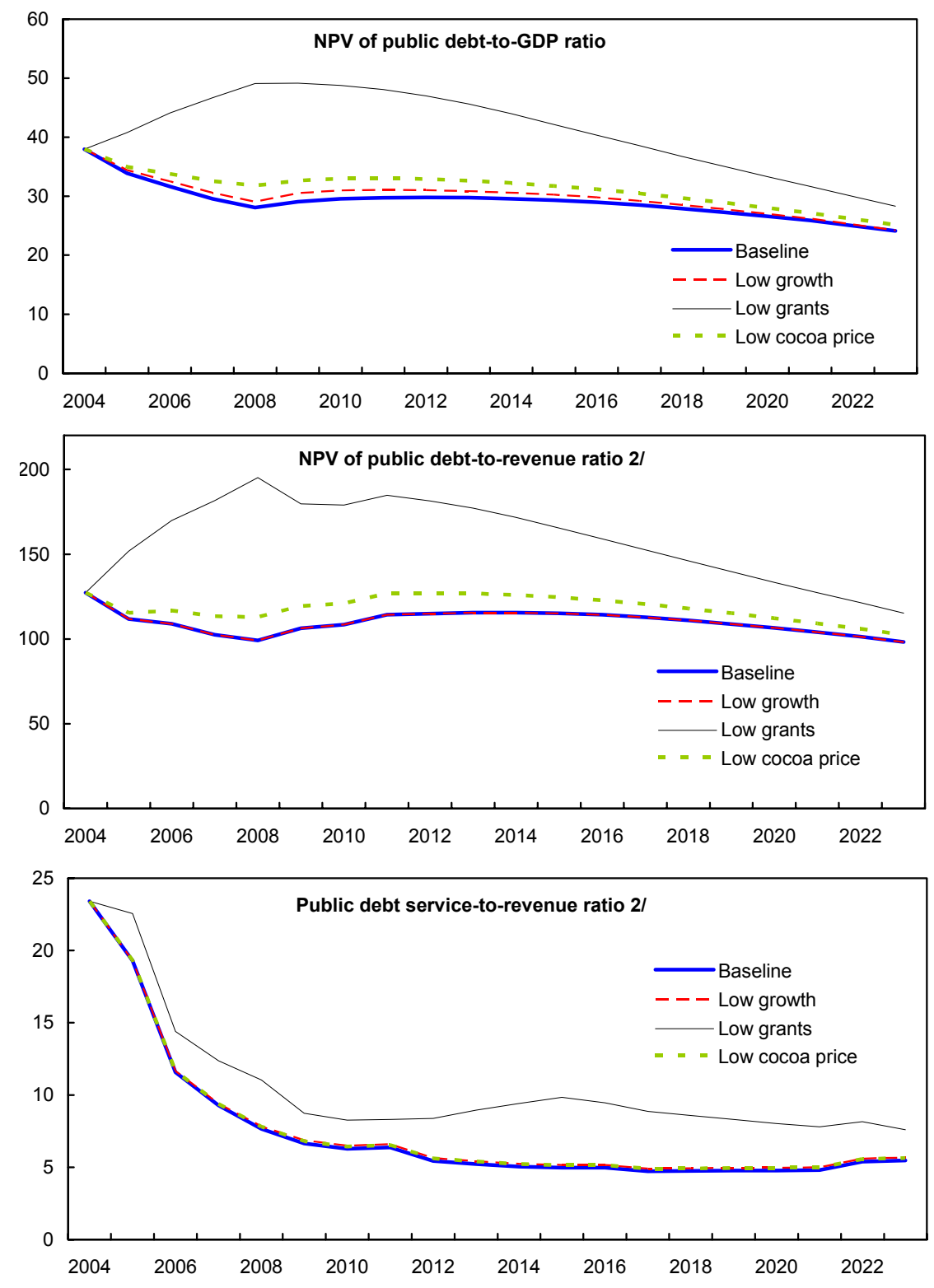

Source: Figure 4 in International Monetary Fund, Country Report No.05/292 .

$1 /$ Public sector debt is net present value (NPV) of external public debt and central government net domestic deb. In all cases except for baseline, temporary shocks are applied to the period 2005-2008.

2/ Revenue including grants. 


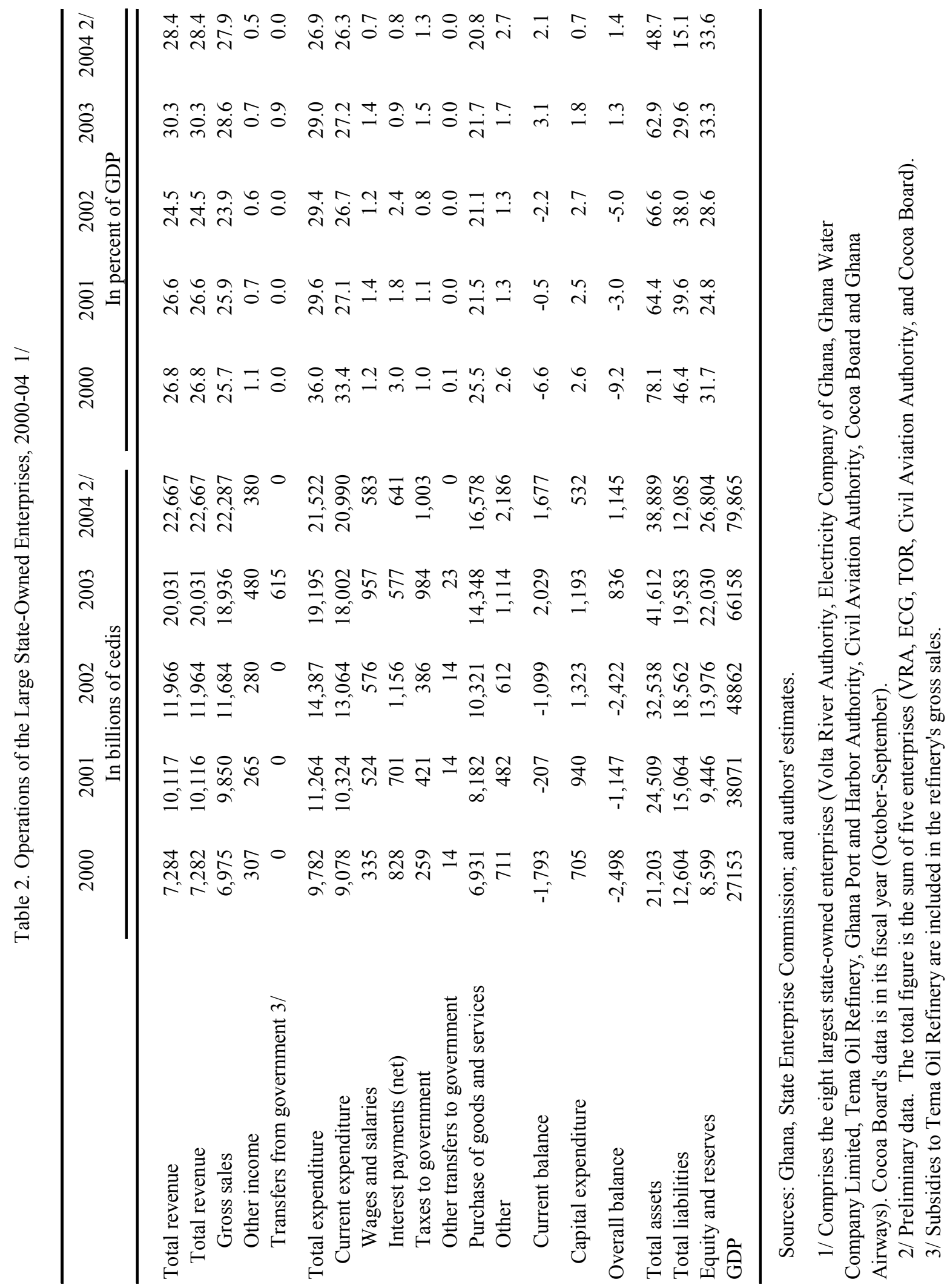




\section{Conceptual Framework For Quantifying QuASI-Fiscal ACTIVITIES}

The IMF's Manual on Fiscal Transparency (2001) indicates that, if pursued, quasi-fiscal activities should be clearly identified and their financial implications reported. QFAs should include all activities under the general direction of government undertaken by the central bank and/or public financial and non-financial public enterprises that are fiscal in nature. These activities are "off-budget," but could be executed through the budget either in the form of an explicit tax, subsidy, or direct expenditure. In other words, QFAs involve a net transfer of public resources to the private sector (households and enterprises) through nonbudget channels. In the event, a wide range of public enterprise operations could be identified as QFAs, such as mispricing, soft budget constraints, and losses due to operating and technical inefficiency. For public financial institutions, QFAs would include subsidized lending or rescue operations, and for the central bank, under-remunerated reserve requirements, sterilization costs related to capital inflows and open market operations, and certain exchange rate practices (see Box 1 for further elaboration on the typical range of QFAs).

For non-financial public enterprises, a common practice is to use the "end-product approach" detailed in Petri et al. (2002) to quantify quasi-fiscal operations, as this methodology takes account of data limitations. ${ }^{5}$ It does so by utilizing available data on relevant end-user and/or benchmark prices which reflect cost recovery, information on collection rates/billing and demand (or consumption). ${ }^{6}$ In many developing countries, this output-based data is usually timelier, and more reliable than financial information. ${ }^{7}$ Nonetheless, the estimated QFAs should be treated with some caution because they rely on specific assumptions about key variables (such as pricing), and general uncertainty surrounding the reliability of public enterprise data-given the lack of oversight, financial monitoring, and reporting requirements of such data in many developing countries. Using the end-product approach, the paper presents QFA estimates for four of Ghana's largest state-owned enterprises-Volta River Authority (VRA), Electricity Company of Ghana (ECG), Ghana Water Company Limited (GWCL), and Tema Oil Refinery (TOR)-based on the aggregate of (i) mispricing, defined as the value of output provided at the benchmark international/regional price or cost

\footnotetext{
${ }^{5}$ For example, the end-product approach is used by Petri et al. (2002) to estimate QFAs for Ukraine and Azerbaijan, Freinkman et al. (2003) for Armenia, Cossé (2003) for Romania, and by the IMF in establishing structural conditionality in a Fund-supported program for the Kyrgyz Republic (IMF, 2003a).

${ }^{6}$ The present analysis is based on comprehensive production and less detailed financial data provided by the Ghanaian authorities on several public enterprises and the Bank of Ghana, generally covering the period 2000-04.

${ }^{7}$ If consolidated financial accounts are available, then an alternative methodology for estimating the magnitude of QFAs is the "financial balance approach". This approach is often difficult to apply as it relies on detailed information concerning revenue, expenditure, input costs, arrears on inputs and taxes, as well as under investment. Appendix I elaborates the two methodologies employed by Petri et al. (2002).
} 
recovery, less the value of output at actual prices; (ii) commercial and technical losses, defined as the value of output supplied at actual prices, less billing; and (iii) the accumulation of new arrears. ${ }^{8}$

Box 1. Types of Quasi-Fiscal Activities

Activities related to non-financial public enterprises

- $\quad$ Mispricing: The pricing of commercial activities below-market or cost recovery.

- $\quad$ Provision of non-commercial services: The delivery of social services that are provided, for example, free of charge or below cost recovery, without being reflected in the government's budget.

- $\quad$ Soft budget constraints: The tolerance of arrears, leading to distortions in the allocation of resources. Arrears are tantamount to an implicit subsidy, lost revenue for the enterprise, and lost tax revenue to the budget. Arrears often result from a lack of a strong payment culture, including from budget entities, government departments and state-owned enterprises.

- Barter and offset arrangements: These arrangements reduce both revenue and costs (expenditures), making it difficult to calculate the precise magnitude of the quasi-fiscal activity.

- Operating inefficiency: Technical losses and unmetered/unbilled consumption (including from theft) arising from poor operating performance, and resulting in low-collection rates.

Activities related to public financial institutions

- $\quad$ Subsidized lending and rescue operations or bailouts: This includes below-market and preferential lending rates, poorly secured and sub-par loans, and mispriced loan guarantees. Rescue operations of both financial and non-financial public enterprises should be conducted through the budget.

- Under remunerated reserve requirements: The central bank often does not remunerate, or pays lower-than-market interest rates on commercial bank reserve requirements.

- Operations related to the exchange rate system: These can include multiple exchange rates and subsidized exchange risk insurance.

- $\quad$ Sterilization operations: Operations to sterilize capital inflows and manage liquidity through open market operations can entail significant losses to the central bank. As these losses must ultimately be covered by the government they are considered a QFA, even though they do not entail a (direct) tax or subsidy element. Alternatively, operations that generate central bank profits would improve the fiscal situation when these are remitted to the budget.

For public financial institutions, the paper uses the methodology suggested by Mackenzie and Stella (1996), who estimate the aggregate QFA of the central bank as the net income-or

\footnotetext{
${ }^{8}$ Technical losses emerge from a number of sources, including theft or unbilled consumption, and system losses related to the deterioration and lack of maintenance of the capital stock.
} 
more precisely, net loss-reflected on its income statement. ${ }^{9}$ The central bank's net income is considered as a QFA because of its effect on the magnitude of profit transfers and dividends to the budget. If large central bank losses accrue, for example, sooner or later they will impact on the financial requirements of the government. ${ }^{10}$

\section{The Scope And Coverage Of Quasi-Fiscal Activities}

A number of non-financial public enterprises do not operate on a commercial basis and rely on state support for their activities. Some of these enterprises serve social policy (culture, communications, media) and other public policy objectives (transportation), while others are engaged in quasi-fiscal and/or non-commercially oriented activities (see Box 2). Irrespective of their policy objectives, the financial performance of these non-commercial enterprises should be reflected in the measure of the extended public sector. While the government's intention is clearly to make public enterprises financially self-sustained, profitable, and hence able to contribute to the budget, several enterprises - particularly some major ones - suffer from weak performance and may need government assistance to improve the situation.

The contribution to the budget (through taxes and profits/dividends) by public enterprises is relatively small at about $1 \frac{1}{2}$ percent of GDP in 2003 (Table 3). However, it should also be recognized that direct financial support is comparatively low, with only two such enterprises receiving direct budget subsidies (TOR and VRA, Table 4). More recently, the Ghanaian authorities have begun to pressure public enterprises to enhance their performance and to transfer any profits and dividends to the budget as a legal requirement. ${ }^{11}$ With a strengthening in the macroeconomic situation, some profitable enterprises have begun to emerge (Cocoa Board and Ghana Ports and Harbor Authority), and, consequently, government revenue from these entities should rise in future but perhaps only slowly.

\footnotetext{
${ }^{9}$ Quasi-fiscal activities are evident among some of Ghana's financial institutions but lack of information prevent the quantification of these operations (which nevertheless, are understood to include below-market and preferential lending rates).

${ }^{10}$ As stressed in Dalton and Dziobek (2005), International Financial Reporting Standards require that losses be recorded on the central bank's income statement and charged against capital and reserves. When the losses result in negative net worth, this must be shown as a negative item in the equity section of the balance sheet until such time as action is taken to cover the losses, either through recapitalization or other financial restructuring of the institution.

${ }^{11}$ The requirement to remit profits and dividends to the government is established in the Financial Administration Act which was adopted in 2004.
} 


\section{Box 2. Commercial Orientation of Public Enterprises in Ghana}

A number of criteria could be used to gauge the orientation of a public enterprise. Such criteria could include, pricing policies, managerial independence, relations with government, financial conditions, and governance structure. The classification is relevant because, in principle, the activities of non-commercial enterprises should be included in a broad measure of the public sector. Based on the suggested criteria, 19 of 32 wholly-owned public enterprises in Ghana are judged to have a non-commercial orientation, including most of the largest entities (Electricity Company of Ghana, Ghana Airways, Ghana Cocoa Board, Ghana Water Company, Tema Oil Refinery, and Volta River Authority, see table below).

- Pricing policy. The authorities report that 28 of the 32 public enterprises set prices according to cost recovery, or market forces, including the Tema Oil Refinery where a price mechanism to reflect cost recovery was adopted in February 2005. Utility prices (water and electricity) are set by the Public Utilities Regulatory Commission (see Box 3) according to an automatic (quarterly) adjustment formula.

- Employment policy. It appears that the government grants significant managerial independence to its wholly-owned state enterprises. The authorities report that only one has civil servants in a managerial position, though Board members are appointed by the government. Almost all have enterprise-specific labor contracts that are negotiated separately from those of public sector employees.

- $\quad$ Relations with government. Half of these enterprises benefit from government loans or guarantees, although only a handful benefit from tax and regulatory exemptions. The former includes most of the large enterprises (utilities, transportation, and energy), while in the latter, the most important beneficiary is Ghana Railway Corporation.

- $\quad$ Financial conditions. Partial data suggest that several of these enterprises operate at a loss, or with low profitability (exceptions include Ghana Cocoa Board and the Ports and Harbor Authority). These enterprises largely finance their operations through the accumulation of debt, payment arrears, and depletion of the capital stock. The public utilities currently operate at a loss, although the authorities intend to improve their performance through financial restructuring, technical, and managerial improvements (in particular, raising collections, billing, and metering).

- Governance structure. The authorities report that every wholly-owned public enterprises produce annual reports (which are publicly available), and that only three do not undertake external audits (Ghana National Petroleum Corporation, National Theatre of Ghana, and Volta Hotel). 


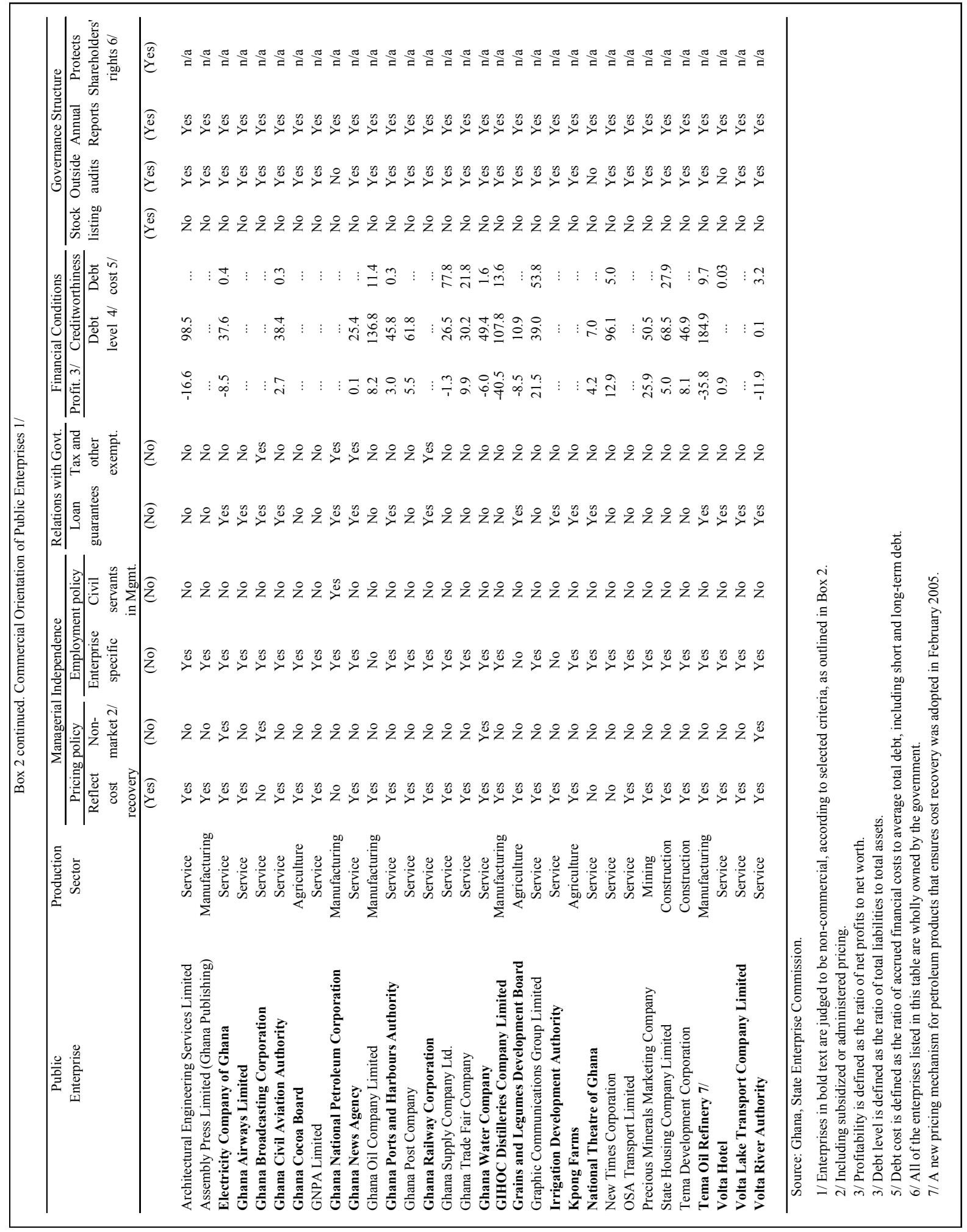


Table 3. Tax and Dividend Payments by

State-Owned Enterprises, 1999-2003

\begin{tabular}{lrrrrr}
\hline & 1999 & 2000 & 2001 & 2002 & 2003 \\
\hline \multicolumn{5}{c}{ (In billions of cedis) } \\
Tax & 227.1 & 258.6 & 421.2 & 386.1 & 984.0 \\
Dividends & 6.5 & 7.8 & 10.7 & 1.1 & 6.1 \\
Total & 233.6 & 266.4 & 431.8 & 387.2 & 990.0 \\
(percent of GDP) & 1.1 & 1.0 & 1.1 & 0.8 & 1.5 \\
\hline
\end{tabular}

Source : IMF (2005b), Attachment IV, Table 49.

Table 4. Budget Subsidies to State-Owned Enterprises, 2003-05

\begin{tabular}{lrrr}
\hline & 2003 & 2004 & $\begin{array}{c}\text { 2005 } \\
\text { Budget }\end{array}$ \\
& \multicolumn{3}{c}{ (In billions of cedis) } \\
Tema Oil Refinery & 156.0 & 1772.0 & 350.0 \\
Volta River Authority & 273.0 & 351.0 & 0.0 \\
Total & 429.0 & 2123.0 & 350.0 \\
(percent of GDP) & 0.6 & 2.7 & 0.4 \\
\hline
\end{tabular}

Source : IMF (2005b), Attachment IV, Table 50.

\section{A. Non-Financial Public Enterprises}

Four large public enterprises account for the majority of quasi-fiscal operations in Ghana, and the nature and scope of these activities are discussed below.

\section{Volta River Authority}

The VRA is a vertically-integrated company which generates and transmits electricity across Ghana for industrial, commercial and domestic use. It produces electricity from both hydroand oil-fired generation facilities (since 1999) to serve about seven major bulk customers, including the ECG, which is the state-owned electricity distribution company (see below). ${ }^{12}$

\footnotetext{
${ }^{12}$ The addition of thermal capacity in 1999 increased overall costs of power generation in Ghana, but at the same time enhanced the reliability of supply. The company generally tries to maximize the use of hydro to minimize cost, but water levels in the Akosombo Dam largely determine the hydrothermal mix. Recently, the split is about 65-70 percent in favor of hydro.
} 
Until the Volta Aluminum Company (VALCO) closed in 2003, it was the VRA's most important customer, consuming one-third of its power generation. The VRA had a long-term contract with the VALCO to supply power at a preferential price, which was about half the level of cost recovery, and hence, a significant source of past unbudgeted subsidies. ${ }^{13} \mathrm{At}$ present, the VRA's installed capacity is sufficient to meet Ghana's power needs, and any shortfall or excess supply is accounted for through trade among countries in the region (Togo, Benin and Cotê d'Ivoire). Through a subsidiary, the Northern Electricity Department, the VRA is also involved in distributing power to the northern region of the country.

The VRA's financial performance improved over the period 2000-04 (Appendix Table A1). Sharp exchange rate depreciation in 2000 led to a decline in the real value of tariffs and a net loss of 3.9 percent of GDP during that year. A gradual increase in the tariff and the shutdown of the VALCO led to a net profit of 0.2 percent of GDP in 2004. With regard to the balance sheet, the VRA holds the highest valued assets among the state-owned enterprises, amounting to 32.3 percent of GDP in 2004. About 40 percent of its liabilities are long term external loans. Current- and medium-term liabilities comprise of domestic borrowing and trade credits.

There are two main sources of recent QFAs from the company's operations, stemming from mispricing and arrears as a consequence of low collection rates. In general, the wholesale tariffs levied by the VRA reflect cost recovery for most customers, but, until recently, the average tariff rate was much lower on account of the heavy discount provided to the VALCO. In 2002, for example, the average tariff rate was US 3.1 cents/kWh, and this increased to an average of US 4.6 cents/kWh in 2003-04, when power was no longer being supplied to the aluminum smelter (Table 5). This compares with average costs of US 5.1 cents/kWh in 2002, and US 4.5 cents/kWh in 2004. Consequently, the VRA's quasi-fiscal deficit from mispricing moved from the equivalent of 2.6 percent of GDP in 2002, to a surplus of 0.2 percent of GDP two years later. ${ }^{14}$ Thus, the main beneficiary of mispricing was the aluminum smelter, which was effectively receiving a cross-subsidy paid by the other customers of the VRA.

According to official data, the collection rate has remained stable recently at 85 percent of billed power sales. The remaining arrears have been largely due to poor payment performance on the part of the ECG, in turn reflecting frequent payment delays from government ministries, departments and agencies, and other public enterprises. The extent of VRA's arrears is estimated to be equivalent to 0.6 percent of GDP per annum over the period

\footnotetext{
${ }^{13}$ The contract between the VRA and VALCO ended in 2003 (it was signed in 1967) and this led to a dispute between the two parties concerning the future price. At about the same time, the private owner of the VALCO entered Chapter 11 proceedings in the United States, and this, combined with the tariff dispute played an important role in the company's closure.

${ }^{14}$ In 2004, the government acquired ownership of the VALCO and has recently restarted its operations (although no output was produced during 2005). In the event, the terms of any power arrangement will have significant implications for the financial performance of the VRA.
} 
2002-04. ${ }^{15}$ This, combined with the activities related to mispricing suggest that the VRA's aggregate QFA has fallen significantly, from 3.3 percent of GDP in 2002 to less than $1 / 2$ percent more recently.

Overtime, these QFAs have been financed mainly by the accumulation of arrears and debt, depletion of the capital stock through under-investment, and more recently through debt relief. Concerning arrears, the Ministry of Finance and Economic Planning takes the lead in an annual exercise to settle cross-debts among the large wholly-owned public enterprises (VRA, ECG, GWCL, and TOR), and the central government. Through this exercise, the inter-enterprise arrears and any taxes which are owing are netted out, and either the central government transfers budget resources to clear the books, or it writes off any outstanding enterprise debts. Compared with other public enterprises, VRA's financial condition is satisfactory, although it is inadequate to maintain the capital stock. Indeed, the World Bank estimates that US\$ 148 million (about 1.7 percent of GDP) in critical investment is required to lift the enterprise's operations back to an acceptable standard. ${ }^{16}$ The VRA's activities have also been financed through debt relief in the context of the enhanced HIPC Initiative amounting to US\$144.2 million (equivalent to 1.6 percent of GDP). Also, the government has committed to provide further annual debt relief to the VRA until 2008.

While the magnitude of the VRA's quasi-fiscal activities has declined significantly during the past several years-mainly on account of the closure of the VALCO-the enterprise is also engaged in a program to improve both its financial and operating performance. Two key elements in this regard are to (i) find new sources of financing to reduce capital costs and (ii) reduce fuel expenses. The latter is the primary motivation behind Ghana's participation in the West African Gas Pipeline project, in which the VRA holds the country's equity interest. ${ }^{17}$ Construction of this pipeline has begun and when completed in 2007, will supply the company with a cheaper source of fuel to operate its thermal generators.

\footnotetext{
${ }^{15}$ Technical losses, at about 4-5 percent of power generation are not excessive and have not been factored into the estimate of the QFA.

${ }^{16}$ These investments include improvements to the power grid and power transfer capability. For more details, see World Bank (2004).

${ }^{17}$ The West African Gas Pipeline project involves equity participation from the governments of Ghana, Togo, Benin, Nigeria, and two private partners (Shell and Chevron).
} 
Table 5. Estimated Quasi-Fiscal Activities of Volta River Authority, 2000-04

\begin{tabular}{|c|c|c|c|c|c|}
\hline & 2000 & 2001 & 2002 & 2003 & 2004 \\
\hline & \multicolumn{5}{|c|}{ (In billions of cedis, unless otherwise noted) } \\
\hline Total Supply (GwH) (1) & 7834.0 & 8029.0 & 8203.0 & 6720.0 & 7051.0 \\
\hline Supply to VALCO (2) $1 /$ & $\ldots$ & $\ldots$ & 2063.0 & 248.8 & 10.2 \\
\hline Total Sales Revenue (billion cedis) (3) & 877.0 & 1393.1 & 2028.8 & 2710.4 & 2941.0 \\
\hline Avg. Bulk Supply Tariff (BST) (cedis/ kWh) (4) & $\ldots$ & $\ldots$ & 247.9 & 395.0 & 426.0 \\
\hline BST for VALCO (cedis/ kWh) (5) & $\ldots$ & $\ldots$ & 131.1 & 259.5 & 259.5 \\
\hline Unit Cost per kWh (cedis) (6) & $\ldots$ & $\ldots$ & 397.0 & 531.0 & 406.0 \\
\hline Collection rate (percent) $(7)$ & $\ldots$ & $\ldots$ & 85.0 & 85.0 & 85.0 \\
\hline QFA from mispricing $(8)=(1) *((4)-(6))$ & $\ldots$ & $\ldots$ & 1290.3 & 904.2 & -141.3 \\
\hline (percent of GDP) & $\ldots$ & $\ldots$ & 2.6 & 1.4 & -0.2 \\
\hline Of which VALCO $(9)=(2) *((5)-(6))$ & $\ldots$ & $\ldots$ & 565.4 & 2.1 & 1.5 \\
\hline (percent of GDP) & & & 1.2 & 0.0 & 0.0 \\
\hline QFA from arrears $(10)=(3) *(100-(7))$ & $\ldots$ & $\ldots$ & 304.3 & 406.6 & 441.1 \\
\hline (percent of GDP) & $\ldots$ & $\ldots$ & 0.6 & 0.6 & 0.6 \\
\hline Total QFA & $\ldots$ & $\ldots$ & 1594.6 & 1310.8 & 299.8 \\
\hline (percent of GDP) & $\cdots$ & $\ldots$ & 3.3 & 2.0 & 0.4 \\
\hline \multicolumn{6}{|l|}{ Memorandum item: } \\
\hline GDP & 27,153 & 38,071 & 48,862 & 66,158 & 79,865 \\
\hline
\end{tabular}

Sources: Volta River Authority; and authors' estimates.

1/ Volta Aluminum Company Limited (VALCO).

\section{Electricity Company of Ghana}

The ECG is the distributor of electricity for the southern portion of the country, and it serves mainly business and residential customers. The VRA supplies the ECG with all of its electricity for distribution. In principle, the ECG is to recover its costs through tariff payments, although it does not have the independence to set rates. Instead, since 2001 the Public Utilities Regulatory Commission (PURC) has been tasked to determine tariff rates for both electricity and water, with the objective of full cost recovery (see Box 3). In the past, the PURC had been reluctant to recommend tariff changes-sometimes in response to political interference-although recent practice has improved, with price adjustments generally in line with the automatic pricing formulas. ${ }^{18}$ Consequently, the source of quasi-fiscal operations from the ECG stem mainly from arrears and excessive losses.

\footnotetext{
${ }^{18}$ For example, between 1998 and 2001 utility prices remained unchanged at their 1998 levels, in spite of developments that affected production costs (high inflation, high oil prices, and a significant depreciation of the nominal exchange rate).
} 
Box 3. The Public Utilities Regulatory Commission (PURC)

PURC was established by an Act of Parliament in 1997 (Act 538). In principle, it is an independent body with a mandate to establish and apply criteria, guidelines, and transparent procedures to regulate all aspects of commercial relations between the public utilities and consumers. The PURC is headed by a Chairman and its governing board includes representatives from unions, consumers, and other persons with knowledge of its activities.

The PURC is not subject to the direction or control of any authority in the performance of its functions, and it has the sole legal mandate to set and approve utility tariffs in Ghana. In carrying out this aspect of its mandate, the PURC is to take account of the interests of consumers and investors, as well as assuring the financial viability of the public utilities. As part of a broad strategy to improve the financial performance of the public utilities, in 2001 the PURC established pricing formulas for electricity and water. These formulas are intended to allow for the automatic and quarterly adjustment of these prices in response to several key parameters, such as changes in world oil prices, the nominal exchange rate against the US dollar, inflation, and various service charges. In practice, however, the PURC has often been slow to adjust prices in line with the automatic formulas, although recently, the speed of adjustment has improved. PURC is undertaking a triennial rate review which should be completed in early 2006.

The price of electricity set by the PURC is adequate to ensure full cost recovery, but it is not high enough to offset ECG's inefficiencies. Along with poor management, this has affected the ECG's financial performance. Net losses - although slightly improving recentlyaveraged 0.6 percent of GDP during 2000-04 (Appendix Table A2). ${ }^{19}$ Total liabilities have also fallen, from 5.5 percent of GDP in 2000 to 2.1 percent of GDP in 2004. Like the VRA, the ECG's long term liabilities comprise of external loans, and this accounts for about 40 percent of its total liabilities.

During the past several years, ECG's system loss is about 26 percent of power purchases from the VRA, and this is due to both commercial losses-accounting for 14 percent of this total, and attributed to lack of billing/metering and theft-and technical losses-accounting for 12 percent, and attributed to the poor state of the enterprise's infrastructure. Although there was some improvement in the collection rate in 2003, which rose to 87 percent of billed consumption, it fell back to 84 percent more recently. The lack of timely payment from ministries, departments, agencies and other public enterprises contribute substantially to this low collection rate, which would rise to 95 percent if their electricity bills were paid on time. During the period 2002-04, the estimated QFA from arrears (i.e., non-collection) is the equivalent of about $1 / 2$ percent of GDP, and slightly higher from excessive losses and theft. During the past several years, there has been no improvement (nor further increase) in ECG's quasi-fiscal operations, which amount to just over 1 percent of GDP (Table 6).

\footnotetext{
${ }^{19}$ The exception was in 2001 when a net profit of 0.3 percent of GDP occurred, mainly due to a comparatively small exchange rate loss.
} 
The main beneficiaries of ECG's quasi-fiscal operations are the wide range of consumers, many of which accumulate arrears or take advantage of unbilled consumption. However, a heavy cost is borne by the majority of Ghana's population as ECG's poor financial condition

Table 6. Estimated Quasi-Fiscal Activities of Electricity Company of Ghana, 2000-04

\begin{tabular}{|c|c|c|c|c|c|}
\hline & 2000 & 2001 & 2002 & 2003 & 2004 \\
\hline & \multicolumn{5}{|c|}{ (In billions of cedis, unless otherwise noted) } \\
\hline Total energy sales (GWh) (1) & $2,910.0$ & $3,080.0$ & $3,200.0$ & $3,342.9$ & $3,539.4$ \\
\hline Total sales revenue (2) & 546.1 & $1,010.1$ & $1,552.7$ & $2,272.1$ & $2,544.5$ \\
\hline Average end user tariff (cedis/ kWh) (3) & $\ldots$ & $\ldots$ & 485.0 & 682.0 & 682.0 \\
\hline System loss (percent) & $\ldots$ & $\ldots$ & 26.0 & 26.0 & 26.0 \\
\hline Commercial losses (percent) (4) & $\ldots$ & $\ldots$ & 12.0 & 12.0 & 12.0 \\
\hline Collection rate (percent) (5) & $\ldots$ & $\ldots$ & 80.0 & 87.0 & 84.0 \\
\hline QFA from arrears $(6)=(1) *(3) *(100-(5))$ & $\ldots$ & $\ldots$ & 310.4 & 296.4 & 386.2 \\
\hline (percent of GDP) & $\ldots$ & $\ldots$ & 0.6 & 0.4 & 0.5 \\
\hline QFA from excessive losses/theft $(7)=(4) *(1) *(3) 1 /$ & $\ldots$ & $\ldots$ & 294.9 & 433.2 & 458.6 \\
\hline (percent of GDP) & $\ldots$ & $\ldots$ & 0.6 & 0.7 & 0.6 \\
\hline Total QFA $(8)=(6)+(7)$ & $\ldots$ & $\ldots$ & 605.3 & 729.6 & 844.9 \\
\hline (percent of GDP) & $\ldots$ & $\ldots$ & 1.2 & 1.1 & 1.1 \\
\hline \multicolumn{6}{|l|}{ Memorandum item: } \\
\hline GDP & 27,153 & 38,071 & 48,862 & 66,158 & 79,865 \\
\hline
\end{tabular}

Sources: Electricity Company of Ghana; and authors' estimates.

1/ The estimated QFA for excessive losses include technical losses of 7 percent, which brings these losses in line with the targets set by the Public Utilities Regulatory Commission.

has prevented ongoing investment, not only to improve, but to expand its services. While access to the electricity network is relatively high in Ghana, compared with other subSaharan African countries, this network only reaches 45 percent of the population (Table 7). In addition to arrears, the ECG has financed these QFAs through the accumulation of debt-averaging nearly 5 percent of GDP between 2000-02-and depletion of its capital stock. A portion of the external debt has been written-off in the context of the enhanced HIPC Initiative, amounting to US\$86.9 million (1 percent of GDP). The World Bank estimates that refurbishing and expanding the electricity network in Ghana would require annual investment (including for operations and maintenance) of about US\$117 million (about 1.3 percent of GDP) during the next five years or so (Table 8). ${ }^{20}$ This is compared with the current level of capital expenditures, which is about only 30 percent of the needed amount.

${ }^{20}$ Such investment is expected to lead to an expansion of access to 60 percent of the population. 
To address the current situation, the ECG is focusing on (i) stepping up efforts to collect arrears, (ii) facilitating payment by establishing more cash-collection points, and (iii) pursuing an aggressive policy of disconnecting non-paying customers. The PURC will continue to support the ECG through ensuring that tariffs reflect full cost recovery. Action is also being taken to improve the company's financial position through further debt restructuring to settle all payable/receivables among government entities, and additional annual debt relief from the government through 2008 .

Table 7. Infrastructure Indicators, 2000

\begin{tabular}{lccc}
\hline & $\begin{array}{c}\text { Access to } \\
\text { electricity } \\
\text { network }\end{array}$ & $\begin{array}{c}\text { Access to } \\
\text { improved } \\
\text { water }\end{array}$ & $\begin{array}{c}\text { Access to } \\
\text { improved } \\
\text { sanitation }\end{array}$ \\
\hline Ghana & \multicolumn{2}{c}{ (In percent of population) } \\
Sub-Saharan Africa & 45 & 51 & 23 \\
Low income countries & 24 & 44 & 49 \\
Lower-middle income countries & 26 & 61 & 52 \\
Upper-middle income countries & 89 & 84 & 78 \\
High income countries & 99 & 89 & 90 \\
\hline
\end{tabular}

Source: World Bank, World Development Indicators, 2004.

Table 8. Ghana's Infrastructure Needs, 2004-08

\begin{tabular}{|c|c|c|c|c|c|}
\hline & \multicolumn{3}{|c|}{ Cumulative Needs } & \multicolumn{2}{|c|}{ Annual Average } \\
\hline & Investment & $\begin{array}{c}\text { Operations } \\
\text { and } \\
\text { Maintenance }\end{array}$ & Total & $\begin{array}{c}\text { Estimated } \\
\text { needs }\end{array}$ & $\begin{array}{c}\text { Actual } \\
\text { total } \\
\text { spending }\end{array}$ \\
\hline & \multicolumn{5}{|c|}{ (In millions of US dollars) } \\
\hline Water and Sanitation & 840 & 118 & 958 & 192 & 22 \\
\hline Electricity & 316 & 268 & 584 & 117 & 38 \\
\hline Total & 1,156 & 386 & 1,542 & 309 & 60 \\
\hline
\end{tabular}

Source: Tsibouris et al . (2004), Table 5.

\section{Ghana Water Company Limited}

The GWCL is the main distributor of piped water in Ghana's urban areas, where less than two-thirds of the urban population has access to a potable supply. Earlier, the company had responsibility for operating 210 water systems nationwide, but in the late 1990s most of the smaller systems were transferred to local government authorities (where the estimated rural 
water supply coverage is much lower, at around 46 percent). About half of Ghana's population has access to potable water, and only a quarter to modern sanitation (Table 7).

In recent years, the GWCL has been among the poorest performing of the wholly-owned public enterprises. Net losses averaged 1.6 percent of GDP during 2000-02 and only improved to 0.3 percent of GDP in 2003, largely due to a lower exchange rate loss (Appendix Table A3). With almost no new capital investment, total assets in 2003 (4.4 percent of GDP) were less than half of the level in 2000 (9.6 percent of GDP). Nonetheless, total liabilities also declined from 6.3 percent of GDP in 2000 to 2.6 percent three years later.

Several factors have contributed to this relatively weak performance, although two stand out. The first relates to the poor state of the company's infrastructure, as a consequence of a long period of disinvestment. This is reflected in a high frequency of "pipe burst," and system losses which account for half of its total water production. This loss is above the target for such losses set by the PURC at 45 percent of production, and is significantly greater than the 25-35 percent benchmark established internationally. The system losses are almost evenly split between unaccounted for water (mainly due to technical problems, such as damaged water mains and distribution lines), and commercial losses (including theft and unbilled consumption). The latter is the second major factor driving poor performance, as only half of the company's registered customers have meters installed. The collection rate from metered consumption has remained at about 75 percent during the past several years, although this rate would rise if the settlement of cross-debts is included.

As for the electricity utility, the main source of quasi-fiscal operations for the water company stem from payment arrears and excessive losses. During the past several years, the former is estimated to be equivalent to 0.2 percent of GDP, while the latter is quantified at about $1 / 2$ percent of GDP (Table 9). ${ }^{21}$ Taken together, the quasi-fiscal operations of the GWCL have declined slightly, amounting to about 0.7 percent of GDP in 2004.

The main beneficiaries of GWCL's quasi-fiscal operations are its urban consumers, nearly half of which enjoy free water. However, these consumers also face a heavy cost in the form of a lower quality service (low water pressure and frequent disruption). The transfer of resources has been financed in a similar manner to the ECG, through arrears, the build up of debt, debt relief, and disinvestment. The latter has been quite striking in recent years. The World Bank estimates the annual investment needs for water and sanitation (capital and operations and maintenance) at US\$192 million (2.1 percent of GDP) during the next several years, compared with recent actual outlays of only a fraction of this amount (about 10 percent) (Table 8 ).

\footnotetext{
${ }^{21}$ The estimate for excessive loss includes both commercial ( 25 percent) and a portion of technical losses (about 20 percent), to bring the system loss in line with the PURC's objective for the water company.
} 
To address the current situation, the GWCL is focusing on (i) raising the collection rate through the installation of meters, especially for key commercial customers, (ii) ensuring that non-paying customers are actually disconnected, (iii) facilitating payment by establishing cash-collection points, and (iv) measures to reduce operating costs. Starting in 2005, the World Bank's urban water project (US\$120 million) aims to (i) increase access to the piped water system in Ghana's urban centers through system expansion and rehabilitation and (ii) restoring long term financial stability and sustainability of the GWCL through capacity building and turning over management to the private sector. Also, the PURC will continue to support the GWCL through ensuring that tariffs reflect full cost recovery.

Table 9. Estimated Quasi-Fiscal Activities of Ghana Water Company, 2000-04

\begin{tabular}{|c|c|c|c|c|c|}
\hline & 2000 & 2001 & 2002 & 2003 & 2004 \\
\hline & \multicolumn{5}{|c|}{ (In billions of cedis, unless otherwise noted) } \\
\hline Total water sales (millions of cubic meter) (1) & 90.0 & 89.9 & 85.1 & 110.9 & 120.4 \\
\hline Total sales revenue $(2)$ & 137.1 & 225.6 & 317.4 & 415.2 & 485.2 \\
\hline System losses (percent) (3) & 51.4 & 52.3 & 58.4 & 50.0 & 50.0 \\
\hline Commercial losses (percent) (4) & 25.0 & 25.0 & 25.0 & 25.0 & 25.0 \\
\hline Collection rate (percent) $(5)$ & 86.0 & 77.0 & 74.0 & 75.0 & 75.0 \\
\hline Average tariff (cedis/cubic meter) (6) & $1,523.5$ & $2,509.6$ & $3,730.1$ & $3,742.9$ & $3,742.9$ \\
\hline QFA from arrears $(7)=(2) /(5)-(2)$ & 22.3 & 67.4 & 111.5 & 138.4 & 161.7 \\
\hline (percent of GDP) & 0.1 & 0.2 & 0.2 & 0.2 & 0.2 \\
\hline QFA from excessive losses/theft $(8)=(1) /(3) *(4) *(6) 1 /$ & 126.8 & 212.7 & 343.1 & 373.7 & 405.7 \\
\hline (percent of GDP) & 0.5 & 0.6 & 0.7 & 0.6 & 0.5 \\
\hline Total QFA & 149.2 & 280.0 & 454.6 & 512.1 & 567.4 \\
\hline (percent of GDP) & 0.5 & 0.7 & 0.9 & 0.8 & 0.7 \\
\hline \multicolumn{6}{|l|}{ Memorandum item: } \\
\hline GDP & 27,153 & 38,071 & 48,862 & 66,158 & 79,865 \\
\hline
\end{tabular}

Sources: Ghana Water Company Limited; and authors' estimates.

1/ The estimated QFA for excessive losses include technical and commercial losses equivalent to 45 percent which is the target for system losses set by the Public Utilities Regulatory Commission.

\section{Tema Oil Refinery}

Ghana relies on imports of crude oil and refined product to supply domestic demand for petroleum products. The bulk of the domestic market ( 85 percent) comes from crude oil which is refined by the state-owned TOR.$^{22}$ The TOR secures two-thirds of its crude oil from

${ }^{22}$ About 5 percent of TOR's supply is accounted for by releases from the state-owned Bulk Oil Storage and Transport Company (BOST), which manages Ghana's strategic petroleum reserve. The 
Nigeria (about 30,000 barrels/day) through a bilateral take-or-pay agreement that offers high quality Nigerian Bonny Light crude at a discount off the average world oil price, a 60-day credit facility, and discounted transportation charges. The remainder of TOR's crude inputs come from oil-marketing companies or market traders, who import crude oil through competitive tender (since early 2004) organized until recently by the National Petroleum Tender Board (NPTB). ${ }^{23}$ The remainder of the domestic market (15 percent) is supplied by the import of refined petroleum products by the private sector based on competitive tender. The TOR is the only refinery in Ghana, with a throughput of about 45,000 barrels/day, although it has only recently operated at full capacity because of previous technical and financial difficulties. Consequently, the refinery now benefits from economies of scale that lower production costs, which it passes on to consumers through lower ex-refinery prices (compared with the price of imported refined-petroleum products). During the past several years the refinery has operated at loss, although a small profit emerged in 2004, largely on account of subsidies from the budget (see below, and Appendix Table A4).

Until recently, the government was heavily involved in the pricing of petroleum products (although it was never involved in procurement or distribution), and this had serious adverse effects on TOR's financial performance. Before a new mechanism was adopted in February 2005 (see below), the government effectively administered petroleum product prices and adjusted them only infrequently, and in large jumps to catch up with the prevailing market conditions. For example, average price increases of 30 percent took place in April 2000, 91 percent in February 2001, and 90 percent in January 2003; prices were then held fixed at the January 2003 level, until the new pricing mechanism was adopted in early 2005.

Since 2002, petroleum product prices were to be determined by an automatic and independent formula defined to ensure full cost recovery for the TOR. The basis of the formula was fob Mediterranean product prices, to which TOR's shipping, insurance, and related charges were added to establish the (cost recovery) ex-refinery price. The ex-pump price was then calculated by adding the full pass through of all taxes, levies, and distributor margins. The formula was to be monitored by the NPTB. In the event, the government did not allow the pricing formula to function as intended, and instead, continued to administer prices by government fiat. This policy-designed to achieve social and political goals-had several macroeconomic implications: TOR's financial position continued to be fragile, as the administered price increases failed to ensure full cost recovery; to finance its operations the TOR borrowed heavily, leading to significant exposure and vulnerability of the financial

BOST releases some of its reserves to the domestic market on a regular basis to prevent deterioration of the stock.

${ }^{23}$ The NPTB was established under the Ministry of Energy with the objective of organizing competitive tenders for the supply of crude oil for the TOR, and for refined products imported by the private sector. As part of the deregulation of the petroleum sector, the NPTB was replaced in June 2005 by the National Petroleum Authority. 
sector to world oil price changes; and consumers have not had to face the world price of petroleum products, leading to distortions in consumption and resource allocation.

Thus, the main source of quasi-fiscal operations for the TOR stemmed from mispricing, as the government set ex-refinery prices below cost recovery until a new pricing mechanism was adopted. This resulted in under recovery of the TOR's costs equivalent to 1.8 percent of GDP in 2002 and 0.3 percent in 2003 (Table 10). ${ }^{24}$ Consumers benefited from this under recovery, as it worked to prevent the full cost of world prices and changes in the nominal exchange rate from being reflected in retail fuel prices. However, petroleum subsidies were not an effective means to mitigate the impact of high fuel prices on the poor and vulnerable households in Ghana (see Box 4).

Table 10. Estimated Quasi-fiscal Activities of the Tema Oil Refinery, 2001-03

\begin{tabular}{lrrr}
\hline & 2001 & 2002 & 2003 \\
\hline & \multicolumn{3}{c}{ (In percent of GDP) } \\
QFA from mispricing by product 1/ & & & \\
$\quad$ Premium & -0.4 & 0.3 & -0.1 \\
$\quad$ Kerosene & 0.1 & 0.2 & 0.0 \\
Gasoil & 0.3 & 1.3 & 0.3 \\
RFO & 0.0 & 0.0 & 0.0 \\
Premix & $\ldots$ & $\ldots$ & 0.0 \\
LPG & $\ldots$ & $\ldots$ & 0.1 \\
Total QFA & 0.0 & 1.8 & 0.3 \\
& $($ In billions of cedis) \\
QFA from mispricing by product 1/ & \multicolumn{3}{c}{} \\
$\quad$ Premium & -133.4 & 139.9 & -41.2 \\
Kerosene & 39.0 & 76.8 & 5.6 \\
Gasoil & 115.4 & 626.8 & 175.4 \\
$\quad$ RFO & -4.2 & 18.4 & 22.3 \\
Premix & $\ldots$ & $\ldots$ & 1.8 \\
$\quad$ LPG & $\ldots$ & $\ldots$ & 47.5 \\
Total QFA & 16.8 & 862.0 & 211.4 \\
\hline
\end{tabular}

Source: Authors' estimates.

$1 /$ Computed from the product of the difference in ex-refinery prices (cost recovery price and government ceiling) and consumption of each petroleum product. There is no QFA in 2004 because the government financed TOR's under recovery directly from the budget.

\footnotetext{
${ }^{24}$ The amount of under recovery during 2004 is not considered a QFA since it was financed fully by a direct subsidy from the budget.
} 
Box 4. The Distributional Impact of Petroleum Subsidies

A close examination of Ghana's previous petroleum subsidies suggest they were an ineffective means of protecting the real income of poor households due to the substantial leakage of the benefit to higher income households. Indeed, only a small share of either direct or indirect benefits - through direct consumption of petroleum products and indirect consumption, for example, through transportation services and electricity consumption — reaches the poorest households.

- $\quad$ Concerning the direct benefit of petroleum products consumption, it is estimated that the wealthiest households receive a disproportionate amount of the subsidy with the top quintile receiving 33 percent, compared with 14 percent for the poorest quintile.

- $\quad$ Concerning the indirect benefit, the highest income group absorbs 34 percent of the subsidy, compared with 9 percent for the lowest income group.

In other words, the incidence of the real income burden from the removal of petroleum price subsidies is highly progressive, with the burden from their removal nearly four times higher for highest income groups than for the lowest.

To mitigate the impact of high fuel prices on poor households in Ghana, a number of measures might be taken, such as targeting education through (capitation) grants in vulnerable regions, and social protection programs that select beneficiaries based on key household characteristics (correlated with poverty).

Through the 2005 budget, the government has moved to adopt some of these measures, such as increased grants for education and health services, expanded rural electrification, and extended public transportation to less developed areas.

The under recovery through 2003 was financed primarily by the accumulation of arrears to other public sector enterprises and the government, and bank borrowing. In the latter case, the TOR ran up overdrafts to two commercial banks (including Ghana's largest bank, in which the government has an equity interest) far in excess of prudential limits. At various times in the past, the government has taken over responsibility for this debt and its servicing, which in mid-2004 amounted to cedi 2.2 trillion (equivalent to 2.8 of GDP). The TOR's domestic debt to the banking sector has been as high as 2 percent of GDP, but it has now been reduced to about 0.4 percent of GDP, and should fall further with the deregulation of petroleum product prices.

The government has recently begun the process of deregulating the petroleum sector, and this will have positive implications on the refinery's financial and operating performance, and importantly, will remove a relatively large source of quasi-fiscal activity. Beginning in February 2005, the government adopted a new pricing mechanism that ensures that exrefinery prices reflect full cost recovery for both the TOR and private importers of both crude oil and refined product. ${ }^{25}$ Consequently, prices were raised an average of 50 percent at that

\footnotetext{
${ }^{25}$ Details of recent measures and the pricing mechanism can be found in the IMF's Country Report on Ghana, No. 05/292.
} 
time, and subsequently further in response to rising world oil prices. The TOR is also taking a number of actions to improve its operations, aimed at reducing its costs and enhancing efficiency.

\section{B. Public Financial Institutions}

Public financial institutions are an important source of quasi-fiscal operations in Ghana-for example, in providing bank-financing of TOR's previous under recovery of its costs-but data limitations prevent an analysis of their magnitude. ${ }^{26}$ However, the central bank is also a source of QFAs and comprehensive data is available to gauge the extent of their operations.

The Bank of Ghana is the central bank, which has a mandate defined in both the central bank law and the constitution to, among other things (i) promote and maintain the stability of the currency and direct and regulate the currency system, (ii) encourage and promote economic development, and (iii) regulate and direct the credit and banking system in accordance with the economic policy of the government and the provisions of the Bank of Ghana Law. The central bank describes its monetary policy framework as a variant of an inflation-targeting regime, in which it uses open-market operations to achieve the desired growth in the monetary aggregates, consistent with the (single-digit) inflation target.

The economic development objectives of the Bank of Ghana have led it to become involved in a number of commercial and financial activities that are quasi-fiscal in nature, although such involvement has been curtailed in recent years. For example, the central bank had earlier been involved with non-core activities in both the non-financial (such as brickmaking, livestock production, and agricultural product storage) and financial sector (such as having ownership interests in several commercial and development banks). It was also heavily involved in providing directed credit to the private and public sector, and in guaranteeing both foreign and domestic loans. As indicated in McKenzie and Stella (1996), the major source of Bank of Ghana's quasi-fiscal losses through the 1980s and 1990s were due to foreign exchange guarantees (reflected on the balance sheet as changes in the revaluation account), and a modest amount of subsidized lending to both enterprises and the government. These losses were estimated at about 4-5 percent of GDP per annum during that period.

During the past several years, there have been two sources of quasi-fiscal activities for the central bank, associated with (i) the relatively high cost of conducting open-market operations and sterilizing strong capital inflows, and (ii) the absence of remuneration on commercial banks' deposits held in the central bank to satisfy the primary reserve requirement. $^{27}$ The period 2002-04 experienced rapid growth in the broad monetary

\footnotetext{
${ }^{26}$ Data required to estimate QFAs is by nature commercially sensitive. Understandably, there is a general reluctance to release this information.

${ }^{27}$ In 2000, the primary reserve requirement was 8 percent of banks' deposits which was raised to 9 percent in 2001. The Bank of Ghana also imposes a secondary reserve requirement which was
} 
aggregates in Ghana, as a result of both expansionary fiscal policies and foreign inflows from official and private sources. The central bank engaged in heavy open-market operations during this period to rebuild international reserves to more comfortable levels and to withdraw excess liquidity to reduce inflationary pressures. ${ }^{28}$ The cost of these operations were relatively high-as short-term interest rates reached nearly 40 percent in mid2003-amounting to the equivalent of $1 / 2$ percent of GDP in 2003, rising to nearly 1 percent of GDP in 2004 (Table 11). With regard to the lack of remuneration on primary reserves-which is tantamount to a quasi-fiscal tax imposed by the central bank that should be remitted to the budget - the forgone interest is estimated to have declined steadily from the equivalent of 0.7 percent of GDP in 2000, to 0.3 percent of GDP in 2004. The 91 day Treasury bill rate is used to gauge the extent of unremuneration. Taken together, sterilization costs and the forgone interest on the primary reserve requirement shifted from a quasi-fiscal gain of nearly $3 / 4$ percent of GDP in 2000-which would have had the effect of reducing the overall fiscal deficit of the public sector-to a loss of nearly the same amount in 2004.

Thus, compared with the previous two decades there has been a strong improvement in addressing quasi-fiscal losses of the central bank, although the recent recapitalization with non-marketable and under-remunerated securities remains problematic (see Box 5). The central bank's losses, or persistently low net income, could impair its financial ability to use open market and open-market type operations to absorb liquidity, which adds to inflationary risks.

\section{Summary}

The QFAs of four major non-financial public enterprises and the Bank of Ghana can be summarized as follows.

- $\quad$ Based on recent data, the estimates show that the combined QFAs reached about $63 / 4$ percent of GDP in 2002, before declining to about $23 / 4$ percent of GDP during 2004 (Table 12). ${ }^{29}$ In the earlier period, nearly two-thirds of this activity was related to (i) under-recovery of TOR's refining costs and (ii) the mispricing of electricity by the VRA. Consequently, while QFAs have been reduced recently, they remain significant and influential to the financial performance of the public enterprise sector.

35 percent until July 2005, when it was lowered to 15 percent. Banks must meet the secondary reserve requirement by holding various government and central bank securities (which yield a market-determined rate of return).

${ }^{28}$ Broad money growth was 50 percent during 2002 and 41 percent in 2003, before declining to 27 percent in 2004. Gross international reserves increased threefold to nearly US\$2 billion at end2004, rising from the equivalent of 1.9 months of imports of goods and services at end-2002 to 3.9 months two years later.

${ }^{29}$ An earlier estimate of Ghana's QFAs projected them at about 1.8 percent of GDP in 2003, but this figure was based on projections and not actual data (see Box 5 in IMF (2002)). 
Table 11. Estimated Quasi-Fiscal Activities of the Bank of Ghana, 2000-04

\begin{tabular}{|c|c|c|c|c|c|}
\hline & 2000 & 2001 & 2002 & 2003 & 2004 \\
\hline & & \multicolumn{4}{|c|}{ (In percent of GDP) } \\
\hline Total quasi-fiscal activities $(1)=(2)-(3)$ & -0.7 & -0.7 & -0.5 & 0.0 & 0.6 \\
\hline Cost of sterilization (2) $1 /$ & $\ldots$ & $\ldots$ & $\ldots$ & 0.5 & 0.9 \\
\hline Unremunerated primary reserve requirement (3) 2/ & 0.7 & 0.7 & 0.5 & 0.5 & 0.3 \\
\hline \multicolumn{6}{|l|}{ Memorandum items: } \\
\hline Total primary reserve requirement (billions of cedis) & 547.6 & 710.4 & 945.2 & $1,253.0$ & $1,662.2$ \\
\hline Required primary reserve ratio & 8.0 & 9.0 & 9.0 & 9.0 & 9.0 \\
\hline Total deposits (billions of cedis) & $6,844.4$ & $7,892.9$ & $10,502.6$ & $13,922.7$ & $18,469.3$ \\
\hline Stock of sterilization and Bank of Ghana bills (billions of cedis) & $\ldots$ & $\ldots$ & $\ldots$ & $1,221.5$ & $4,443.1$ \\
\hline 91 day Treasury-bill rate (annual average, percent) & 35.6 & 37.1 & 23.6 & 26.8 & 16.6 \\
\hline Bank of Ghana bill rate (28-56 days, annual average, percent) & $\ldots$ & $\ldots$ & $\ldots$ & $\ldots$ & 16.4 \\
\hline GDP (billions of cedis) & 27,153 & 38,071 & 48,862 & 66,158 & 79,865 \\
\hline
\end{tabular}

Sources: Bank of Ghana; and authors' estimates.

$1 /$ Cost of sterilization is based on the central bank's open-market operations and is calculated using the 91 day Treasury-bill rate.

2/ Calculated from total primary reserve requirement on commercial banks' deposits and 91 day Treasury-bill rate. The unremunerated reserve requirement is a quasi-fiscal tax imposed by the central bank, which should be remitted to the budget through profit/dividend transfers. Hence, it is subtracted from the total quasi-fiscal activities of the central bank.

- $\quad$ Since 2002, QFAs of the major non-financial public enterprises have declined markedly, while those of the Bank of Ghana have increased. The former have fallen from the equivalent of more than 7 percent of GDP in 2002, to about 2 percent two years later. The latter has risen by about 1 percentage point of GDP during the same period, on account of the high cost of central bank open-market operations to remove past high levels of domestic liquidity and to sterilize strong capital inflows.

- The QFAs of ECG and GWCL have declined only slightly during the past few years, reflecting the slowness of progress in improving these enterprises' operating performance.

\section{Quasi-Fiscal Activities And The Fiscal Position}

Extending the coverage of the fiscal indicators to include the central government, the eight major public enterprises (noted in Table 2), and the QFAs of the central bank offers a clearer picture of Ghana's recent fiscal stance. In this case, the current and overall deficit of the public sector deteriorates significantly. The overall deficit of the central government averaged about $6 \frac{1}{2}$ percent of GDP over the period 2000-04, but this increases to about 9.3 percent under a broader measure of the extended public sector (Table 13). During the same period, the current account surplus-which highlights developments for recurrent expenditure-declines only slightly from 3.2 percent of GDP in 2000 to 21/2 percent in 2004. 
Box 5. The Central Bank's Holdings of Government Securities

The balance sheet of the Bank of Ghana shows a small increase in net worth during the period 2000-04 (Appendix Table A5), as a result of several infusions of capital in the form of "revaluation" and "TOR" bonds.

- $\quad$ Revaluation bonds. In the 1980 s, the government issued these bonds to the central bank to help offset losses stemming from the subsidization of foreign exchange rate risk. More recently, these bonds have been used to recapitalize the central bank; revaluation bonds were issued in 1995, 1997, and again in 2003 (table below).

- $\quad$ TOR-related bonds. To help reduce TOR's debt burden to the commercial banks the government issued several banks a series of "TOR" bonds. A portion of these bonds were transferred from a systemically important commercial bank to the central bank, to reduce its exposure to the petroleum sector.

According to international accounting standards, however, an item can only be recognized as an asset when it is probable that the item will give rise to a future flow of economic benefits, and that it can be reliably measured. Some of the revaluation stock held by the central bank may not meet the definition of an asset. Consequently, under international accounting standards the central bank might be considered as "insolvent," as the face value of these securities would be deducted from the central bank's assets leaving a gap in the balance sheet. It is an open question whether or not central banks need capital to effectively carry out its functions (Stella, 1997). However, a Financial System Stability Assessment for Ghana (IMF, 2003b) stressed recently that the central bank's relatively large holdings of non-earning assets weakens it financial capability to conduct monetary and foreign exchange market activity, and its independence.

Government Securities Held by the Bank of Ghana, 2000-04

\begin{tabular}{llllll}
\hline & 2000 & 2001 & 2002 & 2003 & 2004 \\
\hline
\end{tabular}

(In billions of cedis)

Stock of "revaluation bonds"

Non-interest bearing (perpetual), issued in 1995 and 1997

Non-interest bearing, issued in $2003 \mathrm{1} /$

Interest bearing, issued in $19962 /$

Interest bearing, issued in 2003 3/

Total

$\begin{array}{rrrrr}1,302.4 & 1,302.4 & 1,302.4 & 1,302.4 & 1,302.4 \\ \ldots & \ldots & \ldots & 1,844.2 & 1,844.2 \\ 590.7 & 590.7 & 590.7 & 590.7 & 590.7 \\ \ldots & \ldots & \ldots & 670.2 & 670.2 \\ 1,893.1 & 1,893.1 & 1,893.1 & 4,407.5 & 4,407.5\end{array}$

Stock of "Tema Oil Refinery (TOR) bonds" 4/

TOR bonds, interest bearing, issued in 2003 5/

Petroleum finance bonds, interest bearing, issued in 2004 6/

Total

\begin{tabular}{rrrrr}
$\ldots$ & $\ldots$ & $\ldots$ & 468.9 & 468.9 \\
$\ldots$ & $\ldots$ & $\ldots$ & $\ldots$ & 800.2 \\
$\ldots$ & $\ldots$ & $\ldots$ & 468.9 & $1,269.0$ \\
\hline
\end{tabular}

Sources: Bank of Ghana; and author's estimates.

1/ Issued at end-2003 and maturing in 2011.

2/ In 1996, the government accumulated an overdraft position with the central bank which was securitized with the issuance of government bonds, bearing an interest rate of 4 percent.

3/ Issued at end-2003 maturing in 2012, carrying an interest rate equivalent to the Bank of Ghana prime rate.

4/ Bonds issued to cover the under recovery of costs of the TOR.

5 / The interest rate is set at 4.5 percent above the quarterly (annualized) rate of consumer price inflation,

maturity is 2007. These bonds were initially issued to Ghana Commercial Bank (GCB) but subsequently

transferred to the Bank of Ghana to reduce GCB's overdraft with the central bank.

6/ The interest rate is set at 5 percent per annum, maturity is 2009 . 
Table 12. Summary of Estimated Quasi-fiscal Activities, 2000-04

\begin{tabular}{|c|c|c|c|c|c|}
\hline & 2000 & 2001 & 2002 & 2003 & 2004 \\
\hline & \multicolumn{5}{|c|}{ (In percent of GDP) } \\
\hline Non-financial public enterprises & 0.5 & 0.8 & 7.2 & 4.2 & 2.1 \\
\hline Tema Oil Refinery & $\ldots$ & 0.0 & 1.8 & 0.3 & 0.0 \\
\hline Volta River Authority & $\ldots$ & $\ldots$ & 3.3 & 2.0 & 0.4 \\
\hline Electricity Company of Ghana & $\ldots$ & $\ldots$ & 1.2 & 1.1 & 1.1 \\
\hline Ghana Water Company Limited & 0.5 & 0.7 & 0.9 & 0.8 & 0.7 \\
\hline Bank of Ghana & -0.7 & -0.7 & -0.5 & 0.0 & 0.6 \\
\hline Unremunerated reserve requirement & 0.7 & 0.7 & 0.5 & 0.5 & 0.3 \\
\hline Cost of sterilization & $\ldots$ & $\ldots$ & $\ldots$ & 0.5 & 0.9 \\
\hline Total & -0.2 & 0.1 & 6.7 & 4.2 & 2.7 \\
\hline
\end{tabular}

Source: Authors' estimates.

Extending the coverage of the fiscal indicators also changes the picture of fiscal adjustment over the period 2000-04. Indeed, the magnitude of consolidation over this five year period is very impressive; the broader fiscal deficit of the extended-public sector drops from about 18 percent of GDP to below 3 percent, compared with a decline of about 6 percentage points of GDP for the central government alone. The scope of adjustment for the extended public sector is thus partly due to central government effort, and more importantly, the rapidly improving prospects of a number of public enterprises-in particular, increased profitability of the Cocoa Board and significantly reduced losses for the TOR and VRA.

The extent of past QFAs raises the stock of domestic debt of the extended public sector, but on present projections should not prevent the government from reaching its medium-term objective of halving the ratio of domestic debt to GDP from its end-2002 level by end-2005. Although this goal is aimed at domestic debt of the central government, the magnitude of debt reduction of the extended public sector is consistent with this target. At end-2002, the domestic liabilities of the major non-financial public enterprises-stemming mainly from past quasi-fiscal activities - and the central government amount to about 47 percent of GDP (Table 14). By end-2003, this figure had fallen by 10 percentage points of GDP, and preliminary data for 2004 (not shown in the table) register a further decline of about the same magnitude. It is important to note, however, that this measure of domestic debt does not include contingent liabilities that may arise from quasi-fiscal operations, and which could be significant in the case of Ghana (see Box 6). The recent sharp decline in total domestic debt is due to a host of factors; fiscal consolidation efforts, strong growth, and improved performance of public enterprises (which lowered their short-term borrowing requirements).

Enhancing the financial and operating performance of the non-financial public enterprises will require substantial investment, with implications for Ghana's debt sustainability. Taking account of this investment-which is assumed to be financed by external borrowing on concessional terms-in an extended DSA, shows that the NPV of the ratio of debt to GDP would rise to just over 100 percent in 2005, compared with 34 percent for the central 
government alone (Figure 2). However, Ghana's public debt should remain sustainable (see Appendix II for details of the DSA of the broader public sector).

Table 13. Extended Public Sector Balance, 2000-04

\begin{tabular}{lrrrrr}
\hline & 2000 & 2001 & 2002 & 2003 & 2004 \\
\hline Central government balance (1) & -9.7 & -9.0 & -6.8 & -4.4 & -3.6 \\
Non-financial public enterprises balance (2) 1/ & -9.2 & -3.0 & -5.0 & 1.3 & 1.4 \\
QFAs of the Bank of Ghana (3) & -0.7 & -0.7 & -0.5 & 0.0 & 0.6 \\
& & & & & \\
Extended public sector balance (4)=(1)+(2)-(3) & -18.1 & -11.3 & -11.3 & -3.0 & -2.8 \\
& & & & & \\
Memorandum items: & 0.5 & 0.8 & 7.2 & 4.2 & 2.1 \\
Non-financial public enterprises' quasi-fiscal activities & -6.4 & 3.9 & -2.5 & 7.7 & 10.3 \\
Extended public sector current balance 1/ & & & &
\end{tabular}

Source: Authors' estimates.

1/ Extended public sector current balance includes current balance of the central government and non-financial public enterprises and QFAs of the Bank of Ghana.

Table 14. Domestic Debt, 2000-04

\begin{tabular}{lrrrrrr}
\hline & 2000 & 2001 & 2002 & 2003 & 2004 \\
\hline & \multicolumn{5}{c}{ (In percent of GDP) } \\
Domestic debt of the central government (1) & $\ldots$ & 20.9 & 23.9 & 18.3 & 15.2 \\
Domestic liabilities of non-financial public enterprises (2) & $1 /$ & 26.1 & 22.3 & 23.5 & 19.2 & $\ldots$ \\
Total domestic debt (3)=(1)+(2) & $\ldots$ & 43.2 & 47.4 & 37.5 & $\ldots$ \\
\hline
\end{tabular}

Sources: Ghana, Ministry of Finance and Economic Planning; and authors' estimates.

$1 /$ Includes current and medium-term liabilities of the largest eight enterprises and the domestic long-term debt of Tema Oil Refinery. 
Figure 2: Net Present Value (NPV) of Ratio of Public Debt to GDP, 2005-23 1/

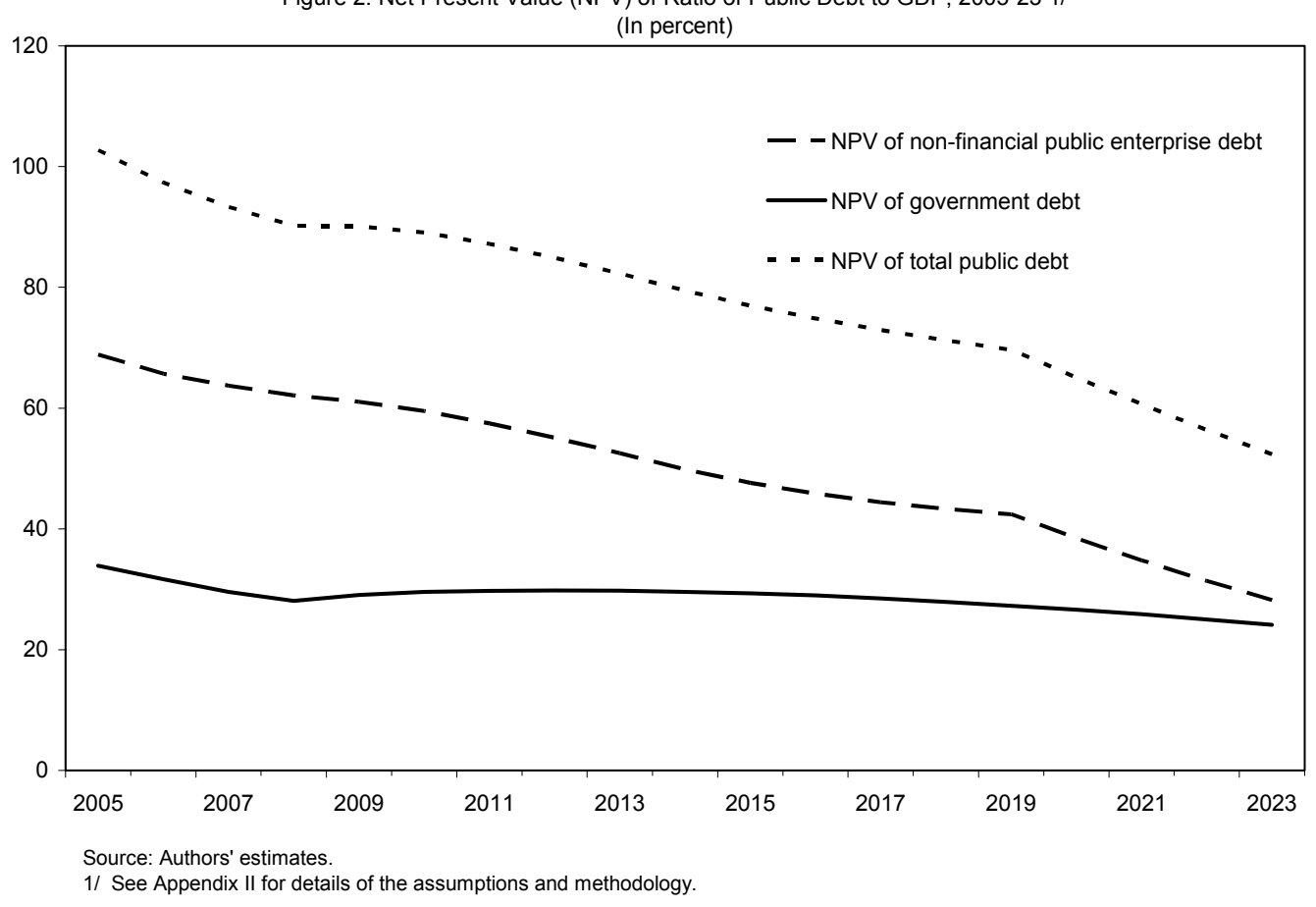

\section{Box 6. Contingent Liabilities: The Case of Ghana Airways}

The existence of quasi-fiscal operations affect both fiscal and debt sustainability through losses that must eventually be absorbed by the budget. QFAs can also generate implicit contingent liabilities that add to the government's external debt. Including these potential liabilities would add further clarity of the "true" underlying fiscal position, and their quantification should be encouraged. The case of Ghana Airways provides a case in point.

Ghana Airways was the country's state-owned national airline, which ceased operation in July 2004 after five consecutive years of losses, and having amassed US\$170 million (about 1.6 percent of GDP) in debt. The debt consists of loans (US\$50 million), overdue supplier's credits (US\$100 million), and arrears (US\$21 million). A debt committee (including an external auditor) has been established by the government to engage creditors and validate the liabilities. Once the committee finishes its work, the government will decide how to manage any of its potential debts. Ghana Airways' assets are also being evaluated by an external auditor.

While Ghana Airways' existing loans carry no government guarantee, many of the creditors are other public enterprises such as the Port and Harbor Authority, and the Civil Aviation Authority. Of the domestic component of the outstanding loans, 40 percent is from other public enterprises, 17 percent from the Bank of Ghana, and 4 percent from Ghana Commercial Bank.

In addition, the government is liable for severance payments to Ghana Airways' former employees, and the 2005 budget has made some provision for this. A government task force has also been set up to help expedite resolution of this issue. 


\section{Policy Implications And Conclusions}

During the past decade or more, Ghana has undertaken extensive structural reforms that have liberalized product and financial markets, and reduced the government's extensive involvement in economic activity. A wide ranging divestiture program also led to a significant decline in the number and scope of public enterprises, although this did not include many of the largest and economically important entities, especially in the energy sector and public utilities. This is an ongoing concern since many of these enterprises continue to engage in quasi-fiscal activities. Also, a number of public financial institutions-including the central bank-engage in such operations; however, the full extent of their involvement remains to be quantified.

The extensive nature of quasi-fiscal activities in Ghana-although declining recently-has several macroeconomic and structural policy implications.

- QFAs remain significant, amounting to 23/4 percent of GDP in 2004. When these activities are included in expanded coverage of the fiscal indicators, a clearer fiscal picture emerges. Indeed, the overall fiscal deficit shifts from an average of $6 \frac{1}{2}$ percent of GDP during the period 2000-04 for the central government alone, to more than 9 percent of GDP including the QFAs. A consequence of these large deficits is the accumulation of domestic debt for the broader public sector which amounted to 37 percent of GDP in 2003, compared with just over 18 percent for the central government alone.

- $\quad$ The poor performance of public enterprises, mainly driven by QFAs, imposes both a financial and economic burden on the economy. Poor financial performance raises the public sector borrowing requirement and puts upward pressure on interest rates, while the latter impedes private sector development and productivity. Without strong public enterprises, investments required to upgrade Ghana's public infrastructure-particularly in the energy sector and utilities-are unlikely to take place, with adverse consequences for private investment and economic growth.

- $\quad$ As these quasi-fiscal losses must eventually be absorbed by the budget, there is little prospective room to maneuver to expand spending on growth-enhancing and povertyreducing social programs to achieve the Millennium Development Goals. The government recognizes the urgent need to improve the financial and operating performance of the remaining public enterprises, but this will take some time to achieve. In the meantime, some measures can help to stem the quasi-fiscal losses, such as ensuring full cost recovery pricing, settling payment obligations in a timely manner, raising collection rates, and cutting off non-paying customers. In addition to reducing the QFAs, the government should make every effort to bring them on budget to heighten transparency and accountability for their existence.

- $\quad$ The failure to provide remuneration on commercial banks' primary reserve requirements is equivalent to a quasi-fiscal tax, which represents forgone revenue to 
the budget. The relatively high cost of sterilization more than offsets the lack of this remuneration, giving rise to quasi-fiscal losses for the Bank of Ghana; therefore, eliminating the transfer of profits and dividends to the budget. Strengthening the income position of the Bank of Ghana would help eliminate a potential concern that in its monetary operations, the central bank would not be unduly influenced by its own profitability. Also, persistent losses could impair its ability to use open-market operations to absorb liquidity which adds to inflationary risks.

- As quasi-fiscal operations have the same impact on resource allocation as taxes and subsidies, the existence of significant QFAs has important implications. In the case of Ghana, these activities have caused serious distortions in energy and water consumption, and in the investment decisions of both the affected public enterprises and the private sector. In addition to the heavy economic costs of these activities, issues of equity and fairness also arise. This is most striking in the case of preferential prices to the former aluminum company, and implicit subsidies for the Tema Oil Refinery's previous under recovery of its costs. 


\section{REFERENCES}

Cossé, Stephané, 2003, “The Energy Sector and Macroeconomic Adjustment in a Transition Economy: The Case of Romania," IMF Policy Discussion Paper No. PDP/03/02 (Washington: International Monetary Fund).

Dalton, John and Claudia Dziobek, 2005, "Central Bank Losses and Experiences in Selected Countries”, IMF Working Paper No. WP/05/72 (Washington: International Monetary Fund).

Freinkman, Lev, Gohar Gyulumyan, and Artak Kyurumyan, 2003, “Quasi-Fiscal Activities, Hidden Government Subsidies, and Fiscal Adjustment in Armenia," World Bank Working Paper No. 16 (Washington: World Bank).

International Monetary Fund, 2005(a), “Ghana: 2005 Article IV Consultation, Third Review Under the Poverty Reduction and Growth Facility, and Request for Waiver of Nonobservance of Performance Criteria and Extension of the Arrangement," IMF Country Report No. 05/292 (Washington: International Monetary Fund).

, 2005(b), "Ghana: Statistical Appendix" (Washington: International Monetary Fund).

, 2003(a), "Kyrgyz Republic: Third Review Under the Poverty Reduction and Growth Facility and Request for Waiver of Performance Criteria," IMF Country Report No. 03/216 (Washington: International Monetary Fund).

, 2003(b), "Ghana: Financial System Stability Assessment Update," IMF Country Report No. 03/396 (Washington: International Monetary Fund).

, 2002, "Ghana: Fourth Review Under the Poverty Reduction and Growth Facility, Requests for Waiver of Performance Criteria and For Extension of the Commitment Period," IMF Country Report No. 02/38 (Washington: International Monetary Fund). ,2001, Manual on Fiscal Transparency, (Washington: International Monetary Fund, Fiscal Affairs Department).

Mackenzie, G.A., and Peter Stella, 1996, Quasi-Fiscal Operations of Public Financial Institutions, IMF Occasional Paper No. 142 (Washington: International Monetary Fund)

Petri, Martin, Günther Taube, and Aleh Tsyninki, 2002, "Energy Sector Quasi-Fiscal Activities in the Countries of the Former Soviet Union," IMF Working Paper No. WP/02/60 (Washington: International Monetary Fund). 
Stella, Peter, 1997, “Do Central Banks Need Capital?”, IMF Working Paper 97/83 (Washington: International Monetary Fund).

Tsibouris, G., N. Kinoshita, R. York, C. Briceno-Garmendia, and M. Andrade, 2004, "Ghana: Note on Public Investment and Fiscal Policy" (Unpublished: Washington: International Monetary Fund). A shortened version of this note is published as Chapter VI of "Public Investment and Fiscal Policy: Summaries of the Pilot Country Studies," http://www.imf.org/external/np/pp/eng/2005/040105b.htm (Washington: International Monetary, Fund Fiscal Affairs Department).

World Bank, 2004, "The Electricity Sector," Ghana Energy Policy Economic and Sector Working Papers (unpublished: Washington: World Bank). 


\section{Appendix I}

\section{Alternative Approaches to Estimating Quasi-Fiscal Activities}

This paper follows the end-product approach as suggested by Petri et al. (2002) to estimate quasi-fiscal activities (QFAs) for Ghana's major public enterprises. This methodology assumes the following:

Let:

Q be the quantity of output (or product sold)

P* be the benchmark of cost recovery output price

$\mathrm{P} \quad$ be the actual price

c be the collection ratio

Then:

(1) Arrears at actual prices $=\mathrm{Q} \times \mathrm{P} \times(1-\mathrm{c})$

(2) Mispricing of output $\quad=\mathrm{Q} \times\left(\mathrm{P}^{*}-\mathrm{P}\right)$

$=$ value at market prices less value at actual prices

(3) Total QFA

$=(1)+(2)$ which, after rearranging terms

$=\mathrm{V} \times \mathrm{P}^{*}-\mathrm{V} \times \mathrm{P} \times \mathrm{c}$

$=$ Value at market prices less actual collections

This compares with the financial balance approach which is relatively data intensive.

Let:

Q(i) be the quantity of a subsidized input (for example, energy)

$\mathrm{P}^{*}$ (i) be the market of cost-recovery input price

$\mathrm{P}(\mathrm{i}) \quad$ be the actual input price

$\mathrm{P}(\mathrm{a})$ be the cost recovery output price at actual costs (for example, electricity)

$\mathrm{R}$ be the actual revenues

$\mathrm{C}$ be the actual costs of the enterprise

$\mathrm{U}$ be the value of underinvestment

A be the value of arrears on inputs and taxes

For cost recovery to hold, the actual revenues of an enterprise plus the mispricing of the output and its arrears must equal its actual costs plus the sum of the mispricing of inputs, underinvestment, and the arrears on inputs and taxes.

Then:

Total revenues

$$
\begin{aligned}
& =\mathrm{Q} \times \mathrm{P}(\mathrm{a}) \times \mathrm{c}+\mathrm{Q} \times(\mathrm{P}(\mathrm{a})-\mathrm{P})+\mathrm{Q} \times \mathrm{P} \times(1-\mathrm{c}) \\
& =\text { actual revenue }+ \text { mispricing of output }+ \\
& \text { arrears on collections }
\end{aligned}
$$


(5) Total costs

(3) Total QFA
$=\mathrm{C}+\mathrm{Q}(\mathrm{i}) \mathrm{x}(\mathrm{P} *(\mathrm{i})-\mathrm{P}(\mathrm{i}))+\mathrm{U}+\mathrm{A}$

$=$ actual costs + mispricing of inputs + underinvestment + arrears on inputs and taxes $=(5)-(4)$ which, after rearranging terms $=(5)-$ actual revenues

Petri et al. (2002) note that the financial balance approach implicitly includes excessive losses as part of the QFAs because the actual costs are equal to the sum of normal costs and excessive losses. In comparison, under the end-product approach excessive losses would need to be added to QFAs in equation (3). 


\section{Appendix II}

\section{Assumptions Underlying the Public Sector Debt Sustainability Analysis}

This appendix outlines the assumptions and methodology used to extend the public debt sustainability analysis (DSA) presented in Section II of the main text. This extension relates to the inclusion of the debt dynamics of the eight largest wholly-owned public enterprises in Ghana (Volta River Authority, Electricity Company of Ghana, Ghana Water Company Limited, Tema Oil Refinery, Ghana Port and Harbor Authority, Civil Aviation Authority, Ghana Cocoa Board, and Ghana Airways). The macroeconomic assumptions underlying the DSA (covering the period 2005-23) include:

- $\quad$ Real GDP growth of 5.5 percent and inflation averaging 4.4 percent per annum;

- $\quad$ Export and import growth of 7.6 and 5.5 percent, respectively, per annum;

- $\quad$ Central government revenue of 23 percent of GDP and non-interest current expenditure of 14.5 percent per annum. This implies primary balance (including grants), over the projection period; and

- $\quad$ Official grants of 4 percent per annum.

Public enterprise debt in this extended DSA comprise current and medium-term liabilities of the eight enterprises noted above, plus the long-term liabilities of Ghana Airways (now defunct) and TOR. ${ }^{1}$ The starting point for the extended DSA is the assumption that the public enterprises can finance current operations-that is, they begin the scenario in overall current balance-but that they require external financing to meet their investment objectives. Further assumptions include:

- An upfront investment during 2005-09 to raise the quality of public infrastructure (water and electricity) in line with the World Bank's needs assessment for Ghana, and ongoing outlays for operations and maintenance (about 1.2 percent of GDP per annum);

- $\quad$ Financing for the required investment is on concessional terms, comparable to those offered by bilateral donors for project support; and

- $\quad$ A discount rate used to calculate the net present value of 5 percent.

\footnotetext{
${ }^{1}$ The long-term liabilities of Ghana Airways and TOR are included in this analysis since this debt was not taken into account in the previous DSA.
} 


\section{APPENDiX TABLES}

Table A1. Volta River Authority: Financial Statements, 2000-04

\begin{tabular}{|c|c|c|c|c|c|}
\hline & 2000 & 2001 & 2002 & 2003 & $\begin{array}{r}2004 \\
\text { est. }\end{array}$ \\
\hline & \multicolumn{5}{|c|}{ (In millions of cedis) } \\
\hline \multicolumn{6}{|l|}{ Income statement } \\
\hline $\begin{array}{l}\text { Revenues (1) } \\
\text { (in percent of GDP) }\end{array}$ & $\begin{array}{r}877,029 \\
3.2\end{array}$ & $\begin{array}{r}1,393,126 \\
3.7\end{array}$ & $\begin{array}{r}2,028,795 \\
4.2\end{array}$ & $\begin{array}{r}2,710,395 \\
4.1\end{array}$ & $\begin{array}{r}2,984,231 \\
3.7\end{array}$ \\
\hline $\begin{array}{l}\text { Expenses }(2)=(3)+(4)+(5)+(6) \\
(\text { in percent of GDP) }\end{array}$ & $\begin{array}{r}1,894,566 \\
7.0\end{array}$ & $\begin{array}{r}1,696,371 \\
4.5\end{array}$ & $\begin{array}{r}3,179,984 \\
6.5\end{array}$ & $\begin{array}{r}3,321,466 \\
5.0\end{array}$ & $\begin{array}{r}2,644,096 \\
3.3\end{array}$ \\
\hline Total employee compensation (2) & 60,066 & 90,847 & 105,633 & 156,766 & $\ldots$ \\
\hline Purchases of goods and services (3) & 495,130 & $1,068,504$ & $1,830,190$ & $1,703,724$ & $1,708,130$ \\
\hline Rent (4) & 0 & 0 & 0 & 0 & $\ldots$ \\
\hline Other expenditures (5) & 967,598 & 136,350 & 677,906 & 689,324 & $\ldots$ \\
\hline (of which, exchange rate loss) & 833,659 & 26,734 & 458,625 & 299,309 & 2,437 \\
\hline Depreciation (6) & 371,772 & 400,670 & 566,255 & 771,652 & 935,966 \\
\hline Income from operations $(7)=(1)-(2)$ & $-1,017,537$ & $-303,245$ & $-1,151,189$ & $-611,071$ & 340,135 \\
\hline Net interest payments $(8)$ & $-54,314$ & $-62,315$ & $-172,538$ & $-78,623$ & $-198,668$ \\
\hline Other income/losses (9) & 38,047 & 67,857 & 54,608 & 42,037 & $\ldots$ \\
\hline Profit before tax $(10)=(7)-(8)-(9)$ & $-1,033,804$ & $-297,703$ & $-1,269,119$ & $-647,657$ & 141,467 \\
\hline $\operatorname{Tax}(11)$ & 0 & 0 & 0 & 0 & 0 \\
\hline Net profit/loss $(12)=(10)-(11)$ & $-1,033,804$ & $-297,703$ & $-1,269,119$ & $-647,657$ & 141,467 \\
\hline (in percent of GDP) & -3.8 & -0.8 & -2.6 & -1.0 & 0.2 \\
\hline \multicolumn{6}{|l|}{ Balance sheet } \\
\hline Total assets & $11,490,405$ & $13,527,403$ & $16,457,512$ & $22,698,317$ & $26,725,558$ \\
\hline (in percent of GDP) & 42.3 & 35.5 & 33.7 & 34.3 & 33.5 \\
\hline Total liabilities & $3,584,447$ & $4,090,131$ & $5,767,281$ & $5,344,332$ & $7,560,996$ \\
\hline (in percent of GDP) & 13.2 & 10.7 & 11.8 & 8.1 & 9.5 \\
\hline Current liabilities & 946,302 & $1,037,959$ & $2,154,946$ & $1,474,336$ & 979,770 \\
\hline Medium term liabilities & 864,436 & $1,203,591$ & $1,380,079$ & $1,610,823$ & $3,707,215$ \\
\hline Long term liabilities & $1,773,709$ & $1,848,581$ & $2,232,256$ & $2,259,173$ & $2,874,011$ \\
\hline Equity and reserves & $7,905,958$ & $9,437,272$ & $10,690,231$ & $17,353,985$ & $19,164,562$ \\
\hline \multicolumn{6}{|l|}{ Memorandum item: } \\
\hline Capital expenditure & 181,928 & 250,027 & 292,626 & 387,644 & $\ldots$ \\
\hline (in percent of GDP) & 0.7 & 0.7 & 0.6 & 0.6 & $\ldots$ \\
\hline GDP (billions of cedis) & 27,153 & 38,071 & 48,862 & 66,158 & 79,865 \\
\hline
\end{tabular}

Sources: Volta River Authority; and authors' estimates. 
Table A2. Electricity Company of Ghana: Financial Statements, 2000-04

\begin{tabular}{|c|c|c|c|c|c|}
\hline & 2000 & 2001 & 2002 & 2003 & $\begin{array}{c}2004 \\
\text { est. }\end{array}$ \\
\hline & \multicolumn{5}{|c|}{ (In millions of cedis) } \\
\hline \multicolumn{6}{|l|}{ Income statement } \\
\hline Revenues (1) & 546,094 & $1,010,063$ & $1,552,690$ & $2,272,053$ & $2,544,522$ \\
\hline (in percent of GDP) & 2.0 & 2.7 & 3.2 & 3.4 & 3.2 \\
\hline Expenses $(2)=(3)+(4)+(5)+(6)$ & 930,052 & 886,579 & $1,920,625$ & $2,666,189$ & $2,799,362$ \\
\hline (in percent of GDP) & 3.4 & 2.3 & 3.9 & 4.0 & 3.5 \\
\hline Total employee compensation (2) & 45,236 & 63,376 & 73,701 & 139,096 & 168,101 \\
\hline Purchases of goods \& services (3) & 412,530 & 673,075 & $1,137,336$ & $1,841,930$ & $2,052,010$ \\
\hline Rent (and other operating expenses) (4) & 71,233 & 87,319 & 117,362 & 155,558 & 118,378 \\
\hline Other expenditures (5) & 354,866 & 7,658 & 251,572 & 166,186 & 42,381 \\
\hline (of which, exchange rate loss) & 354,866 & 7,658 & 251,572 & 166,186 & 42,381 \\
\hline Depreciation (6) & 46,188 & 55,151 & 340,654 & 363,419 & 418,492 \\
\hline Income from operations $(7)=(1)-(2)$ & $-383,958$ & 123,484 & $-367,935$ & $-394,136$ & $-254,840$ \\
\hline Net interest payments (8) & 52,323 & 56,279 & 71,000 & 69,307 & 15,869 \\
\hline Other income/losses (9) & 10,488 & 42,938 & 71,512 & 153,633 & 77,935 \\
\hline Profit before tax $(10)=(7)-(8)-(9)$ & $-435,409$ & 95,919 & $-380,462$ & $-328,976$ & $-208,424$ \\
\hline $\operatorname{Tax}(11)$ & 0 & 0 & 0 & 0 & 0 \\
\hline Net profit/loss $(12)=(10)-(11)$ & $-435,409$ & 95,919 & $-380,462$ & $-328,976$ & $-208,424$ \\
\hline (in percent of GDP) & -1.6 & 0.3 & -0.8 & -0.5 & -0.3 \\
\hline \multicolumn{6}{|l|}{ Balance sheet } \\
\hline Total assets & $1,597,538$ & $2,066,649$ & $6,178,474$ & $6,984,024$ & $7,374,792$ \\
\hline Current Assets & 584,967 & 877,947 & $1,308,016$ & $1,778,290$ & $1,757,366$ \\
\hline Fixed \& other assets at cost & $1,012,571$ & $1,188,702$ & $4,870,458$ & $5,205,734$ & $5,617,426$ \\
\hline $\begin{array}{l}\text { Accumulated depreciation and amortization } \\
\text { (in percent of GDP) }\end{array}$ & 5.9 & 5.4 & 12.6 & 10.6 & 9.2 \\
\hline Total liabilities & $1,678,797$ & $1,963,143$ & $2,613,294$ & $2,814,205$ & $2,253,214$ \\
\hline (in percent of GDP) & 6.2 & 5.2 & 5.3 & 4.3 & 2.8 \\
\hline Current liabilities & 610,475 & 999,233 & $1,248,706$ & $1,553,562$ & 965,003 \\
\hline Long term liabilities & 870,229 & 744,831 & $1,075,788$ & 674,242 & 718,853 \\
\hline Other liabilities & 198,094 & 219,079 & 288,800 & 586,401 & 569,358 \\
\hline Equity and reserves & $-81,260$ & 103,506 & $3,565,180$ & $4,169,820$ & $5,121,578$ \\
\hline \multicolumn{6}{|l|}{ Memorandum item: } \\
\hline Capital expenditure & 242,517 & 161,000 & 181,068 & 267,050 & 316,611 \\
\hline (in percent of GDP) & 0.9 & 0.4 & 0.4 & 0.4 & 0.4 \\
\hline GDP (billions of cedis) & 27,153 & 38,071 & 48,862 & 66,158 & 79,865 \\
\hline
\end{tabular}

Sources: Electricity Company of Ghana; and authors' estimates. 
Table A3. Ghana Water Company Limited: Financial Statements, 2000-04

\begin{tabular}{|c|c|c|c|c|}
\hline & 2000 & 2001 & 2002 & 2003 \\
\hline & \multicolumn{4}{|c|}{ (In millions of cedis) } \\
\hline \multicolumn{5}{|l|}{ Income statement } \\
\hline Revenues (1) & 137,118 & 225,616 & 317,434 & 415,235 \\
\hline (in percent of GDP) & 0.5 & 0.6 & 0.6 & 0.6 \\
\hline Expenses $(2)=(3)+(4)+(5)+(6)$ & 573,220 & 631,148 & 727,143 & 537,900 \\
\hline (in percent of GDP) & 2.1 & 1.7 & 1.5 & 0.8 \\
\hline Total employee compensation (2) & $\ldots$ & 51,117 & 58,348 & 84,994 \\
\hline Purchases of goods \& services (3) & 221,322 & 146,052 & 206,333 & 278,148 \\
\hline \multicolumn{5}{|l|}{ Rent (4) } \\
\hline Other Expenditures (5) & 351,898 & 351,624 & 391,424 & 107,828 \\
\hline (of which, exchange rate loss) & 351,898 & 351,624 & 391,424 & 107,829 \\
\hline Depreciation (6) & $\ldots$ & 82,355 & 71,038 & 66,930 \\
\hline Income from operations $(7)=(1)-(2)$ & $-436,103$ & $-405,532$ & $-409,709$ & $-122,665$ \\
\hline Net interest payments (8) & $-40,695$ & $-55,922$ & $-495,154$ & $-57,638$ \\
\hline Other income/losses (9) & 92 & 0 & 27 & -10 \\
\hline Profit before tax $(10)=(7)-(8)-(9)$ & $-476,706$ & $-461,454$ & $-904,837$ & $-180,313$ \\
\hline $\operatorname{Tax}(11)$ & 0 & 0 & 0 & 0 \\
\hline Net profit/loss $(12)=(10)-(11)$ & $-476,706$ & $-461,454$ & $-904,837$ & $-180,313$ \\
\hline (in percent of GDP) & -1.8 & -1.2 & -1.9 & -0.3 \\
\hline \multicolumn{5}{|l|}{ Balance sheet } \\
\hline Total assets & $2,602,444$ & $2,632,361$ & $2,836,713$ & $2,912,689$ \\
\hline (in percent of GDP) & 9.6 & 6.9 & 5.8 & 4.4 \\
\hline Total liabilities & $1,705,443$ & $2,066,922$ & $1,677,110$ & $1,707,244$ \\
\hline (in percent of GDP) & 6.3 & 5.4 & 3.4 & 2.6 \\
\hline Current liabilities & 456,109 & 297,828 & 233,374 & 259,538 \\
\hline Long term liabilities & $1,249,334$ & $1,769,094$ & $1,443,736$ & $1,447,706$ \\
\hline Equity and reserves & 897,001 & 565,439 & $1,159,603$ & $1,205,445$ \\
\hline \multicolumn{5}{|l|}{ Memorandum item: } \\
\hline Capital expenditure & $\cdots$ & $\cdots$ & $\cdots$ & $\cdots$ \\
\hline (in percent of GDP) & $\ldots$ & $\ldots$ & $\ldots$ & $\ldots$ \\
\hline GDP (billions of cedis) & 27,153 & 38,071 & 48,862 & 66,158 \\
\hline
\end{tabular}

Sources: Ghana Water Company Limited; and authors' estimates. 
Table A4. Tema Oil Refinery: Financial Statements, 2000-04

\begin{tabular}{|c|c|c|c|c|c|}
\hline & 2000 & 2001 & 2002 & 2003 & $\begin{array}{r}2004 \\
\text { est. }\end{array}$ \\
\hline & \multicolumn{5}{|c|}{ (In millions of cedis) } \\
\hline \multicolumn{6}{|l|}{ Income statement } \\
\hline Revenues (1) & $2,099,900$ & $3,199,663$ & $3,182,229$ & $4,691,152$ & $6,719,132$ \\
\hline (in percent of GDP) & 7.7 & 8.4 & 6.5 & 7.1 & 8.4 \\
\hline Expenses $(2)=(3)+(4)+(5)+(6)$ & $3,637,681$ & $3,421,354$ & $3,837,181$ & $4,635,916$ & $6,262,532$ \\
\hline (in percent of GDP) & 13.4 & 9.0 & 7.9 & 7.0 & 7.8 \\
\hline Total employee compensation (2) & 11,825 & 18,949 & 33,893 & 47,952 & 61,736 \\
\hline Purchases of goods \& services (3) & $3,558,066$ & $3,312,890$ & $3,678,024$ & $4,284,941$ & $5,896,379$ \\
\hline Rent (and other operating expenses) (4) & 0 & 0 & 0 & 0 & 0 \\
\hline Other expenditures (5) & 29,588 & 51,159 & 76,544 & 161,868 & 158,529 \\
\hline (of which, exchange rate loss) & $\ldots$ & $\ldots$ & $\ldots$ & $\ldots$ & $\ldots$ \\
\hline Depreciation (6) & 38,202 & 38,356 & 48,720 & 141,155 & 145,888 \\
\hline Income from operations $(7)=(1)-(2)$ & $-1,537,781$ & $-221,691$ & $-654,952$ & 55,236 & 456,600 \\
\hline Net interest payments (8) & $-120,589$ & $-417,045$ & $-344,434$ & $-320,678$ & $-335,486$ \\
\hline Other income/losses (9) & 554 & 743 & 144 & 478 & 12,424 \\
\hline Profit before tax $(10)=(7)-(8)-(9)$ & $-1,657,816$ & $-637,993$ & $-999,242$ & $-264,964$ & 133,538 \\
\hline $\operatorname{Tax}(11)$ & 0 & 0 & 0 & 0 & 0 \\
\hline Net profit/loss $(12)=(10)-(11)$ & $-1,657,816$ & $-637,993$ & $-999,242$ & $-264,964$ & 133,538 \\
\hline (in percent of GDP) & -6.1 & -1.7 & -2.0 & -0.4 & 0.2 \\
\hline \multicolumn{6}{|l|}{ Balance sheet } \\
\hline Total assets & $2,787,615$ & $2,898,550$ & $3,283,998$ & $3,657,084$ & $4,724,099$ \\
\hline (in percent of GDP) & 10.3 & 7.6 & 6.7 & 5.5 & 5.9 \\
\hline Total liabilities & $3,938,643$ & $4,687,570$ & $6,072,260$ & $6,714,561$ & $4,344,717$ \\
\hline (in percent of GDP) & 14.5 & 12.3 & 12.4 & 10.1 & 5.4 \\
\hline Current liabilities & $3,185,936$ & $2,511,247$ & $2,507,361$ & $3,240,766$ & $2,754,525$ \\
\hline Long term liabilities & 752,707 & $2,176,323$ & $3,564,899$ & $3,473,795$ & $1,590,192$ \\
\hline Equity and reserves & $-1,151,028$ & $-1,789,020$ & $-2,788,262$ & $-3,057,477$ & 379,382 \\
\hline \multicolumn{6}{|l|}{ Memorandum item: } \\
\hline Capital expenditure & 7,259 & 1,775 & 490,526 & 128,662 & 23,941 \\
\hline (in percent of GDP) & 0.0 & 0.0 & 1.0 & 0.2 & 0.0 \\
\hline GDP (billions of cedis) & 27,153 & 38,071 & 48,862 & 66,158 & 79,865 \\
\hline
\end{tabular}

Sources: Tema Oil Refinery; and authors' estimates. 
Table A5. Bank of Ghana: Financial Statements, 2000-04

\begin{tabular}{|c|c|c|c|c|c|}
\hline & 2000 & 2001 & 2002 & 2003 & 2004 \\
\hline & \multicolumn{5}{|c|}{ (In millions of cedis) } \\
\hline \multicolumn{6}{|l|}{ Income statement } \\
\hline Total income & 271,353 & 436,726 & 673,800 & $1,537,817$ & $1,238,982$ \\
\hline (in percent of GDP) & 1.0 & 1.1 & 1.4 & 2.3 & 1.6 \\
\hline Interest income & 97,058 & 75,296 & 126,908 & 544,409 & 457,578 \\
\hline Commission & 23,502 & 34,773 & 55,336 & 67,452 & 96,255 \\
\hline Discounts & 62,410 & 257,253 & 249,533 & 365,598 & 123,084 \\
\hline Dividend income & 0 & 0 & 2,923 & 3,762 & 3,295 \\
\hline Exchange gains & 76,333 & 8,468 & 217,177 & 431,209 & 527,636 \\
\hline Other & 12,050 & 60,936 & 21,923 & 125,387 & 31,134 \\
\hline Total expense & 256,326 & 389,164 & 483,798 & $1,315,844$ & $1,514,730$ \\
\hline (in percent of GDP) & 0.9 & 1.0 & 1.0 & 2.0 & 1.9 \\
\hline Interest expense & 47,089 & 46,961 & 61,532 & 505,305 & 840,100 \\
\hline Administration & 135,462 & 193,323 & 240,681 & 402,215 & 292,870 \\
\hline Currency and issue & 54,598 & 117,693 & 139,831 & 348,614 & 260,392 \\
\hline Premises and equipment & 19,177 & 31,187 & 41,754 & 59,710 & 121,368 \\
\hline Net income before provisions & 15,027 & 47,562 & 190,002 & 221,973 & $-275,748$ \\
\hline $\begin{array}{l}\text { Provision for overdue advances and diminution } \\
\text { in value of investments }\end{array}$ & 2.205 & $-10,946$ & 10.880 & 4,329 & 399 \\
\hline Provision for currency printing, restructuring, etc. & $-11,232$ & $-32,500$ & $-86,900$ & $-226,000$ & 0 \\
\hline Provision for unreconciled items & 0 & 0 & $-107,405$ & 0 & 78,323 \\
\hline Net income for the period & 6,000 & 4,116 & 113,982 & 302 & $-275,349$ \\
\hline (in percent of GDP) & 0.0 & 0.0 & 0.2 & 0.0 & -0.3 \\
\hline \multicolumn{6}{|l|}{ Balance sheet } \\
\hline Total assets & $8,850,313$ & $9,740,436$ & $13,828,563$ & $24,975,514$ & $36,188,419$ \\
\hline (in percent of GDP) & 32.6 & 25.6 & 28.3 & 37.8 & 45.3 \\
\hline Cash and amounts due from banks & 794,891 & 808,280 & $1,088,603$ & $3,166,193$ & $2,461,160$ \\
\hline Gold & 546,024 & 565,961 & 814,596 & $1,034,425$ & $1,109,235$ \\
\hline Balances with IMF & 222,764 & 255,678 & 313,716 & $5,251,711$ & $5,357,647$ \\
\hline Domestic securities & $4,345,800$ & $4,710,467$ & $6,143,006$ & $5,214,255$ & $6,438,070$ \\
\hline Foreign securities & 72,340 & 940,493 & $3,159,726$ & $8,019,909$ & $11,843,325$ \\
\hline Loans and advances & $1,552,746$ & $1,712,970$ & $1,610,800$ & 608,214 & $6,854,759$ \\
\hline Other assets & $1,162,693$ & 596,750 & 520,558 & $1,464,186$ & $1,783,843$ \\
\hline Property, plant and equipment & 93,528 & 90,378 & 118,660 & 164,709 & 286,843 \\
\hline Development loans and investments & 59,527 & 59,459 & 58,898 & 51,912 & 53,537 \\
\hline Total liabilities & $8,499,984$ & $9,531,926$ & $13,239,259$ & $24,221,550$ & $35,578,787$ \\
\hline (in percent of GDP) & 31.3 & 25.0 & 27.1 & 36.6 & 44.5 \\
\hline Currency in circulation & $2,753,059$ & $3,285,234$ & $4,939,030$ & $6,679,739$ & $7,673,899$ \\
\hline Allocations of Special Drawing Rights & 558,029 & 576,546 & 719,959 & 823,881 & 880,313 \\
\hline Deposits & $1,245,921$ & $1,600,547$ & $2,328,924$ & $3,058,572$ & $10,459,900$ \\
\hline Liabilities to IMF & $2,566,533$ & $2,474,885$ & $3,622,226$ & $8,833,458$ & $9,373,719$ \\
\hline Liabilities under money market operations & 722,402 & 823,514 & $1,315,879$ & $4,143,171$ & $6,182,374$ \\
\hline Other liabilities & 654,040 & 771,200 & 302,284 & 677,250 & $1,008,582$ \\
\hline Deferred income & 0 & 0 & 10,957 & 5,479 & 0 \\
\hline Equity and reserves & 350,329 & 208,510 & 589,304 & 753,963 & 609,631 \\
\hline \multicolumn{6}{|l|}{ Memorandum item: } \\
\hline GDP (billions of cedis) & 27,153 & 38,071 & 48,862 & 66,158 & 79,865 \\
\hline
\end{tabular}

Source: Bank of Ghana. 